\title{
PIGF: A Multitasking Cytokine with Disease-Restricted Activity
}

\author{
Mieke Dewerchin and Peter Carmeliet \\ Laboratory of Angiogenesis and Neurovascular Link, VIB Vesalius Research Center, K.U. Leuven, \\ 3000 Leuven, Belgium \\ Correspondence: peter.carmeliet@vib-kuleuven.be
}

Placental growth factor (PIGF) is a member of the vascular endothelial growth factor (VEGF) family that also comprises VEGF-A (VEGF), VEGF-B, VEGF-C, and VEGF-D. Unlike VEGF, PIGF is dispensable for development and health but has diverse nonredundant roles in tissue ischemia, malignancy, inflammation, and multiple other diseases. Genetic and pharmacological gain-of-function and loss-of-function studies have identified molecular mechanisms of this multitasking cytokine and characterized the therapeutic potential of delivering or blocking PIGF for various disorders.

Since the discovery and cloning of placental growth factor (PlGF) in the early 1990s (Maglione et al. 1991), the characteristic features of this VEGF family member have become increasingly identified. PlGF affects not only endothelial cells but also a whole array of other cell types, and its broad spectrum of pleiotropic activities in various biological processes continues to expand. PlGF is redundant for developmental and physological processes but is more important in conditions of disease. Numerous preclinical models have shown that elevating or lowering the expression levels of PlGF can elicit several disease conditions. Precisely because PlGF has a negligible role in health, it has been suggested that PlGF blockade might inhibit these disease processes without affecting normal health. Meanwhile, clinical evaluation of the therapeutic potential of an anti-PlGF monoclonal antibody (mAb) for cancer has commenced. In this review, we highlight key aspects of the biology of PlGF, with attention to its mechanisms of action, interaction with other molecules, and possible clinical implications. We also discuss unresolved or controversial issues about the role and therapeutic potential of PlGF. Rather than providing an encyclopedic survey, we focus primarily on recent discoveries.

\section{PIGF: CELLULAR ACTIVITIES AND MOLECULAR MECHANISMS}

The human PlGF gene has been mapped to chromosome $14 q 24$. Its sequence spans an 800-kblong DNA segment comprising seven exons. In humans, four isoforms have been describedPlGF-1-4 (Maglione et al. 1991; Hauser and Weich 1993; Cao et al. 1997; Yang et al. 2003) _ whereas mice only express the equivalent of PlGF-2 (DiPalma et al. 1996). Unlike VEGF, which binds to both VEGF receptor (VEGFR)1 (also named fms-like tyrosine kinase-1, or

Editors: Michael Klagsbrun and Patricia D'Amore

Additional Perspectives on Angiogenesis available at www.perspectivesinmedicine.org

Copyright (C) 2012 Cold Spring Harbor Laboratory Press; all rights reserved; doi: 10.1101/cshperspect.a011056

Cite this article as Cold Spring Harb Perspect Med 2012;2:a011056 


\section{Dewerchin and P. Carmeliet}

FLT1) and VEGFR-2 (fetal liver kinase, Flk1/ KDR), PlGF binds only to FLT1 and sFLT1, the natural soluble version of the receptor lacking transmembrane and intracellular domains (Kendall and Thomas 1993). PlGF-2 can also bind to neuropilin (NRP)-1 and -2 because of an insertion of 21 basic amino acids at the carboxyl terminus (Migdal et al. 1998; Persico et al. 1999). PlGF-1 and PlGF-3 are diffusible isoforms, whereas PlGF-2 and PlGF-4 have heparin binding domains (Yang et al. 2003).

\section{PIGF: A Pleiotropic Factor}

PlGF affects different cell types and regulates various biological responses (Fig. 1). One of the activities of PlGF, identified early on, is its effects on vessel growth and maturation (Ziche et al. 1997; Yonekura et al. 1999; Carmeliet et al. 2001). This proangiogenic activity of PlGF relies on direct effects on endothelial and mural cells, as well as on indirect effects on nonvascular cells with proangiogenic activity (Fig. 1). PlGF enhances the proliferation, migration, and survival of endothelial cells (Ziche et al. 1997; Carmeliet et al. 2001; Adini et al. 2002; Fischer et al. 2007; Schmidt et al. 2011), although some of these effects remain debated (see below). This cytokine also stimulates proliferation of mesenchymal fibroblasts and regulates the contractile response of mural cells, organized around the endothelium during collateral vessel growth (Yonekura et al. 1999; Bellik et al. 2005). In addition, PlGF recruits

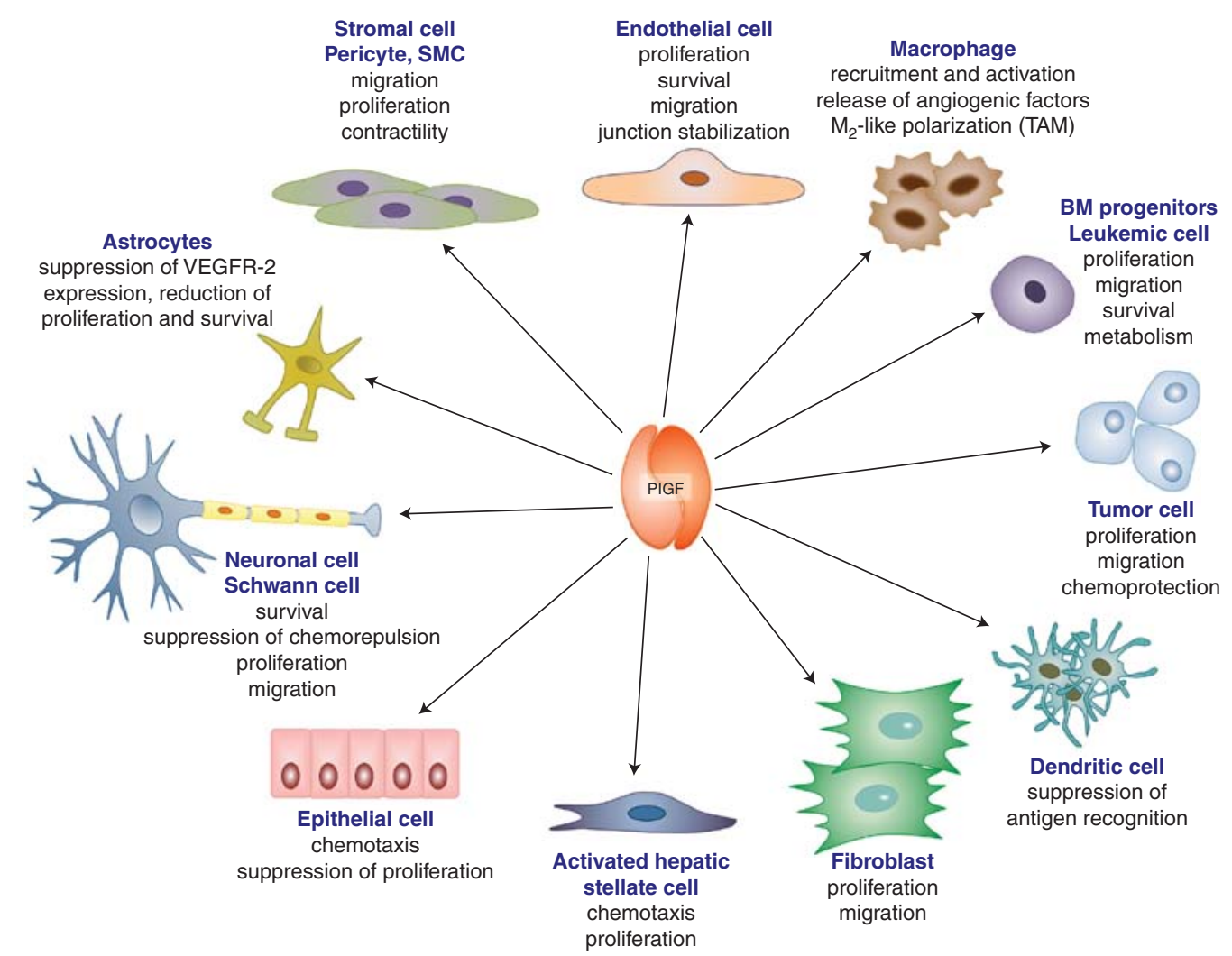

Figure 1. PlGF is a multitasking cytokine affecting various cellular activities. Scheme illustrating the pleiotropic actions of PlGF, including effects on survival, migration, proliferation, metabolism, and activation effects on vascular (endothelial cells, pericytes/smooth muscle cells) as well as nonvascular cells (macrophages, bone marrow-derived progenitors, tumor cells, dendritic cells, fibroblasts, hepatic stellate cells, epithelial cells, neurons, Shwann cells, astrocytes). BM, Bone marrow; SMC, smooth muscle cell; TAM, tumor-associated macrophage. 
myeloid progenitors to growing sprouts and collateral vessels (Hattori et al. 2002; Luttun et al. 2002; Pipp et al. 2003; Rafii et al. 2003; Scholz et al. 2003). Futhermore, PlGF activates and attracts macrophages, capable of releasing angiogenic and lymphangiogenic factors (Selvaraj et al. 2003), and interferes with dendritic cell differentiation and accumulation as well as with antigen recognition (Lin et al. 2007; Rolny et al. 2011).

PlGF recruits mesenchymal progenitors in endochondral ossification (Fiedler et al. 2005), stimulates keratinocyte migration in wound healing (Failla et al. 2000), and enhances chemotaxis of retinal pigment epithelial cells (Hollborn et al. 2006). It also promotes survival of cortical neurons (Du et al. 2010), promotes axon growth cone formation of dorsal root ganglion neurons (Cheng et al. 2004), and stimulates proliferation and migration of Schwann cells (Chaballe et al. 2011a). PlGF enhances growth of tumor cells, both of solid and hematological tumors (Fischer et al. 2008; Schmidt et al. 2011).

\section{Molecular Mechanisms}

It was initially postulated that membrane-anchored FLT1 functions as a ligand trap, because it has a high affinity for VEGF but weak tyrosine kinase activity (Park et al. 1994). According to this model, PlGF would stimulate endothelial cell growth indirectly via displacement of VEGF from the FLT1 decoy receptor, thereby liberating VEGF for activation of VEGFR-2 (Park et al. 1994). Accumulating evidence suggests additional mechanisms. For instance, PlGF up-regulates the expression of angiogenic factors such as VEGF, basic fibroblast growth factor (FGF2), platelet derived growth factor $\beta$ (PDGFB), and matrix metalloproteinases (MMPs), among other molecules (Roy et al. 2005; Marcellini et al. 2006). Furthermore, activation of FLT1 by PIGF induces an intermolecular FLT1:VEGFR-2 cross talk that amplifies VEGF/VEGFR-2 signaling, suggesting that endothelial cells are capable of enhancing their own responsiveness to VEGF by releasing PlGF (Autiero et al. 2003).
PIGF: A Multitasking Disease-Restricted Cytokine

Via activation of FLT1, PlGF induces signaling pathways different from those induced by VEGF. This is the case for macrophages, which predominantly/exclusively express FLT1 (Clauss et al. 1996; Sawano et al. 2001), but also for endothelial cells (Landgren et al. 1998; Autiero et al. 2003), which up-regulate FLT1 in pathological conditions (Shibuya 2006; Huang et al. 2007; Vanheule et al. 2010; FryszNaglak et al. 2011). As shown by mass spectrometry, PlGF and VEGF induce phosphorylation of distinct tyrosine residues of FLT1 (Autiero et al. 2003), further underlining that PlGF and VEGF transmit distinct angiogenic signals through FLT1. Moreover, a recent study reported that FLT1 transmits distinct intracellular signals in response to its different ligands, with only VEGF-B but not VEGF or PlGF stimulating trans-endothelial lipid uptake (Hagberg et al. 2010).

Other studies reported divergent findings about the biological activity of PlGF, and some of its activity profile remains debated. For instance, PlGF has been reported to be ineffective in stimulating endothelial cell growth and migration in vitro, a finding attributed to the weak tyrosine kinase signal activity of FLT1 (Park et al. 1994). It should be noticed, however, that endothelial cells produce abundant PlGF in culture, saturating FLT1 and thereby rendering it unresponsive to exogenous PlGF. Such a hypothesis is supported by findings that endothelial cells from PlGF knockout mice are capable of responding to exogenous PlGF and that loss of PlGF reduces endothelial cell responses (Carmeliet et al. 2001; Schmidt et al. 2011).

PlGF has been also documented to inhibit tumor angiogenesis when overexpressed to supraphysiological levels in tumor cells that coexpress VEGF. In such conditions, VEGF:PlGF heterodimers are formed at the expense of the more proangiogenic VEGF:VEGF homodimers, explaining the reduced angiogenic activity of these tumor cells (Eriksson et al. 2002; Xu et al. 2006; Schomber et al. 2007). Tumor overexpression of a PlGF variant containing an endoplasmic reticulum retention signal similarly promoted VEGF:PIGF heterodimer formation and reduced tumor angiogenesis and growth 
(Bjorndahl et al. 2004). Furthermore, a PlGF variant, unable to bind FLT1 but still capable of heterodimerizing with VEGF, also inhibited VEGF- and PlGF-dependent angiogenesis in cancer (Tarallo et al. 2010). It should be noted, however, that the precise role of the VEGF:PIGF heterodimers remains a matter of debate, as several other studies reported proangiogenic - not antiangiogenic - effects of these heterodimers in vitro and in vivo (DiSalvo et al. 1995; Cao et al. 1996a,b; Autiero et al. 2003). So far, little/nearly nothing is known about the proangiogenic or antiangiogenic activity of naturally occurring VEGF:PlGF heterodimers in physiological settings in vivo. It thus remains unresolved if the antiangiogenic activity of PlGF: VEGF heterodimers only becomes evident when $\mathrm{PlGF}$ is overexpressed at supraphysiological levels.

In any case, it is worth noting that a larger number of studies report a proangiogenic effect for PlGF when it is expressed endogenously by tumor or stroma cells, or when a PlGF transgene is modestly overexpressed by tumor cells (Hiratsuka et al. 2001; Adini et al. 2002; Li et al. 2006; Marcellini et al. 2006; Kerber et al. 2008; Tarallo et al. 2010). Furthermore, genetic neutralization of PlGF inhibits - not stimulates - vessel growth in adipose tissue, tumors, and other injured, ischemic, or inflamed tissues (Table 1). Final resolution of these issues awaits further investigation.

\section{PIGF, REDUNDANT IN DEVELOPMENT AND HEALTH}

Given its pleiotropic activities, it is not surprising that PlGF induces various biological effects in vivo (Table 1). PlGF-deficient mice exhibit normal development, viability, and health, indicating that endogenous PlGF is dispensable for vascular development and homeostasis in the adult (Carmeliet et al. 2001). PlGF is also not required for exercise-induced angiogenesis in the heart or skeletal muscle (Gigante et al. 2004). This redundancy in health is further illustrated by the fact that an sFLT1 trap that neutralizes VEGF, VEGF-B, and PlGF induces a similar phenotype as an anti-VEGF antibody in healthy animals (Malik et al. 2006). A possible explanation for the more important disease-associated role of PlGF is that its expression is low/undetectable in most healthy tissues, but significantly up-regulated in pathologies (Marrony et al. 2003; Fischer et al. 2008). In line herewith, FLT1 expression is also up-regulated in disease (Fischer et al. 2008).

Although PlGF is expressed by trophoblast cells and placental villi in pregnancy (Munaut et al. 2008; Depoix et al. 2011), PlGF-deficient mice are fertile (Carmeliet et al. 2001). However, high sFLT1 levels in the placenta likely neutralize local PlGF (Kendall et al. 1996; Cindrova-Davies et al. 2011; Furuya et al. 2011). PlGF also regulates the maturation of uterine natural killer cells in the endometrium needed for trophoblast invasion (Tayade et al. 2007). Overall, although PlGF is expressed in development, its role is largely redundant.

\section{PIGF, A DISEASE-MODIFYING CANDIDATE}

In contrast to its more enigmatic function in development and health, PlGF has a predominant role in the angiogenic and inflammatory "switch" in various diseases, as shown by studies using pharmacological and genetic inhibition or overexpression approaches (Table 1). Part of its biological activity is mediated by molecular effects on the vasculature, but effects on nonvascular cells are also in play (Fig. 1). PlGF is expressed by various cell types in pathological conditions, including vascular cells, fibroblasts, leukocytes, hepatocytes, bone marrow-derived cells, neurons, epithelial cells, and tumor cells (Table 2). Several stimuli up-regulate the expression of PlGF in disease conditions, ranging from hypoxia, growth factors, hormones, and oncogenes to physical stimuli (Table 2). The PlGF receptor FLT1 and its coreceptor NRP-1 are also up-regulated in disease conditions (Barleon et al. 1997; Gerber et al. 1997; Beck et al. 2002; Neufeld et al. 2002; Shibuya 2006). A possible implication of these findings is that PlGF blockade might inhibit disease processes more selectively than physiological homeostasis and thus evoke fewer side effects. We summarize below the findings on PlGF's 
PIGF: A Multitasking Disease-Restricted Cytokine

Table 1. Phenotypes observed upon gain-of-function and loss-of-function of PIGF

\begin{tabular}{|c|c|c|}
\hline PIGF & Gain of function (GOF) & Loss of function (LOF) \\
\hline General & ND & $\begin{array}{l}\text { Knockout: viable and fertile without } \\
\text { vascular defects (Carmeliet et al. 2001) }\end{array}$ \\
\hline Placenta & $\begin{array}{l}\text { PlGF protein attenuates clinical symptoms } \\
\text { in a mouse model of preeclampsia } \\
\text { (Suzuki et al. 2009) }\end{array}$ & $\begin{array}{l}\text { Knockout: reduced angiogenesis in ovaries } \\
\text { (Carmeliet et al. 2001) } \\
\text { Knockout: altered natural killer cell } \\
\text { differentiation in endometrium (Tayade } \\
\text { et al. 2007) } \\
\text { Excessive release of sFLT1 by villous } \\
\text { trophoblasts reduces plasma levels of } \\
\text { PlGF (and other growth factors) and } \\
\text { causes endothelial dysfunction in } \\
\text { maternal tissues leading to preeclampsia } \\
\text { (Foidart et al. 2009; Furuya et al. 2011) }\end{array}$ \\
\hline Heart & $\begin{array}{l}\text { PlGF-induced revascularization of } \\
\text { ischemic myocardium and vessel } \\
\text { enlargement in remote myocardium }\end{array}$ & $\begin{array}{l}\text { Knockout: impaired angiogenesis and } \\
\text { inflammation in infarct border } \\
\text { (Carmeliet et al. 2001) }\end{array}$ \\
\hline
\end{tabular}
preserve cardiac performance following Knockout: Normal exercise induces infarction (Luttun et al. 2002; Kolakowski et al. 2006; Roncal et al. 2008)

Skeletal muscle PlGF protein or gene delivery: enhances angiogenesis, collateral growth, and angiogenesis (Gigante et al. 2004)

blood flow in ischemic limb (Luttun et al. 2002; Pipp et al. 2003; Babiak et al. 2004); restores microcirculation in aged dystrophic muscle (Gargioli et al. 2008)

Eye

PlGF prevents vessel obliteration in hyperoxia without including neovascularization (Shih et al. 2003)

Local ocular PlGF protein or gene transfer causes hematoretinal barrier breakdown and edema (Miyamoto et al. 2007; Kowalczuk et al. 2011)

Vascular system

PlGF gene delivery increases atherosclerosis, macrophage accumulation, and neovascularization (Khurana et al. 2005)

PlGF gene delivery induces angiogenesis in healthy mice (Roy et al. 2005)

PlGF overexpression in tumor cells improves tumor vessel normalization (Hedlund et al. 2009)

PlGF protein is a vasodilator of resistance arteries (ex vivo) (Osol et al. 2008)

hPlGF-1 protein stabilizes adherens junctions in ECs (Cai et al. 2011)

Knockout: impaired collateral growth in ischemic limb (Carmeliet et al. 2001; Scholz et al. 2003; Gigante et al. 2006)

Knockout: normal exercise-induced angiogenesis (Gigante et al. 2004)

Knockout or aPlGF: impaired choroidal neovascularization (Carmeliet et al. 2001; Rakic et al. 2003; Van de Veire et al. 2010)

Knockout or aPlGF does not impair retinal vascularization during development (Carmeliet et al. 2001; Feeney et al. 2003)

PlGF gene silencing in RPE cells ablates their proangiogenic potential (in vitro) (Akrami et al. 2011)

Knockout: normal blood and lymphatic development (Carmeliet et al. 2001)

PlGF blockage by knockout, aPlGF, or sFLT1 reduces inflammatory cell infiltration in atherosclerotic lesions and (early) lesion size (Khurana et al. 2005; Onoue et al. 2009; Roncal et al. 2010)

Down-regulation of PIGF normalizes tumor vessels, enhancing chemotherapy (Rolny et al. 2011)

Knockout: impaired collateral growth in ischemic limb (Carmeliet et al. 2001; Scholz et al. 2003; Gigante et al. 2006)

Continued 
M. Dewerchin and P. Carmeliet

Table 1. Continued

\begin{tabular}{|c|c|c|}
\hline PIGF & Gain of function (GOF) & Loss of function (LOF) \\
\hline Skin & $\begin{array}{l}\text { PlGF gene delivery accelerates wound } \\
\text { healing (Cianfarani et al. 2006) } \\
\text { Overexpression of PlGF increases skin } \\
\text { vascularization without affecting } \\
\text { lymphatics (Wirzenius et al. 2007) } \\
\text { Overexpression of PlGF enhances } \\
\text { cutaneous delayed-type hypersensitivity } \\
\text { response (Oura et al. 2003) }\end{array}$ & $\begin{array}{l}\text { Knockout: normal blood and lymphatic } \\
\text { development (Carmeliet et al. 2001) } \\
\text { Knockout: impaired skin wound healing } \\
\text { (Carmeliet et al. 2001) } \\
\text { Knockout: reduced cutaneous delayed-type } \\
\text { hypersensitivity response (Oura et al. } \\
\text { 2003) }\end{array}$ \\
\hline Bone and joints & $\mathrm{ND}$ & $\begin{array}{l}\text { Knockout: impaired cartilage and bone } \\
\text { metabolism during fracture repair } \\
\text { (Maes et al. 2006) } \\
\text { Knockout of PlGF and PlGF-FLT1 } \\
\text { antagonist peptide: suppresses disease } \\
\text { development or progression of } \\
\text { rheumatoid arthritis (Yoo et al. 2009) }\end{array}$ \\
\hline Fat tissue & ND & $\begin{array}{l}\text { Knockout or aPlGF reduces de novo adipose } \\
\text { tissue development, in part by reducing } \\
\text { angiogenesis (Lijnen et al. 2006) } \\
\text { Knockout reduces the fraction of brown } \\
\text { adipocytes and stimulates white } \\
\text { adipocyte hypertrophy, promoting } \\
\text { insulin resistance and hyperinsulinemia } \\
\text { (Hemmeryckx et al. 2008) }\end{array}$ \\
\hline Solid tumors & $\begin{array}{l}\text { Overexpression of PlGF in epidermis or } \\
\text { tumor cells: increases tumor growth, } \\
\text { angiogenesis, and metastasis (Adini } \\
\text { et al. 2002; Li et al. 2006; Marcellini } \\
\text { et al. 2006; Kerber et al. 2008); redirects } \\
\text { premetastatic niche (Kaplan et al. } \\
\text { 2005); inhibits tumor angiogenesis and } \\
\text { growth via formation of VEGF/PlGF } \\
\text { heterodimers (Eriksson et al. 2002; } \\
\text { Xu et al. 2006; Schomber et al. 2007; } \\
\text { Tarallo et al. 2010) } \\
\text { PlGF educates CD34 progenitors to } \\
\text { proangiogenic CD11b } \\
\text { myelomonocytes in breast cancer } \\
\text { (Laurent et al. 2011) }\end{array}$ & $\begin{array}{l}\text { Knockout or aPlGF: blockage of tumor } \\
\text { growth, metastasis, lymphangiogenesis, } \\
\text { and angiogenesis (Carmeliet et al. 2001; } \\
\text { Fischer et al. 2007; Coenegrachts et al. } \\
\text { 2010; Van de Veire et al. 2010) } \\
\text { PlGF-Flt-1 antagonist peptide blocks } \\
\text { growth of human xenograft tumors } \\
\text { (Taylor and Goldenberg 2007) } \\
\text { Down-regulation of PlGF is implicated in } \\
\text { TAM polarization to a tumor-inhibiting } \\
\text { M1-like phenotype, anti-tumor immune } \\
\text { responses, and tumor vessel } \\
\text { normalization, decreasing tumor growth } \\
\text { and metastasis and enhancing } \\
\text { chemotherapy (Rolny et al. 2011) } \\
\text { Silencing of PlGF in tumor cells prevents } \\
\text { proangiogenic activity in CD11b }{ }^{+} \text {cells } \\
\text { and slows tumor growth (Laurent et al. } \\
\text { 2011) }\end{array}$ \\
\hline $\begin{array}{l}\text { Hematological } \\
\text { malignancies }\end{array}$ & $\begin{array}{l}\text { PlGF induces migration and/or } \\
\text { proliferation of AML, ALL, and CML cell } \\
\text { lines in vitro (Ikai et al. 2005; Casalou } \\
\text { et al. 2007; Schmidt et al. 2011) }\end{array}$ & $\begin{array}{l}\text { Knockout or aPlGF prolong survival of } \\
\text { imatinib-sensitive and -resistant CML } \\
\text { mice (Schmidt et al. 2011) }\end{array}$ \\
\hline
\end{tabular}


PIGF: A Multitasking Disease-Restricted Cytokine

Table 1. Continued

\begin{tabular}{|c|c|c|}
\hline PIGF & Gain of function (GOF) & Loss of function (LOF) \\
\hline $\begin{array}{l}\text { Bone marrow } \\
(\mathrm{BM}) / \text { blood, } \\
\text { sepsis }\end{array}$ & $\begin{array}{l}\text { PlGF reconstitutes hematopoiesis through } \\
\text { stimulation of stem cell differentiation } \\
\text { and mobilization (Hattori et al. 2002) } \\
\text { PlGF recruits angiogenic BM progenitors } \\
\text { and macrophages to neovessels (Lyden } \\
\text { et al. 2001; Luttun et al. 2002; Pipp et al. } \\
\text { 2003; Kaplan et al. 2005; Li et al. 2006; } \\
\text { Carlo-Stella et al. 2007) } \\
\text { Viral PlGF gene delivery induces PAI1 } \\
\text { plasma levels via mechansms involving } \\
\text { HIF1 } \alpha \text { and miRNA regulation, and } \\
\text { promotes a prothrombotic phenotype } \\
\text { (Patel et al. 2010, 2011) } \\
\text { Overexpression of PlGF in erythroid cells to } \\
\text { mimic sickle cell PlGF levels promotes } \\
\text { pulmonary hypertension in mice } \\
\text { (Sundaram et al. 2010) }\end{array}$ & $\begin{array}{l}\text { Knockout or aPlGF impairs recruitment of } \\
\text { BM progenitors and macrophages to } \\
\text { neovessels (Carmeliet et al. 2001; Fischer } \\
\text { et al. 2007) } \\
\text { Knockout reduces PAI1 plasma levels in } \\
\text { sickle cell disease (Patel et al. 2010, 2011) } \\
\text { Knockout or aPlGF increases morbidity and } \\
\text { mortality in sepsis (Yano et al. 2008) }\end{array}$ \\
\hline Nervous system & $\begin{array}{l}\text { Intramuscular PlGF gene delivery restores } \\
\text { diabetic sensory neuropathy (Murakami } \\
\text { et al. 2011) } \\
\text { PlGF gene: beneficial effects of } \\
\text { mesenchymal stem cell (MSC) therapy of } \\
\text { cerebral ischemic injury was enhanced } \\
\text { upon PlGF gene transduction of the } \\
\text { MSCs (Liu et al. 2006) } \\
\text { PlGF protein is neuroprotective for primary } \\
\text { cortical neurons in vitro (Du et al. 2010) } \\
\text { PlGF-2 protein antagonizes chemorepulsive } \\
\text { effects in DRG neurons (Cheng et al. } \\
\text { 2004) }\end{array}$ & $\begin{array}{l}\text { Knockout of PlGF in astrocytes up-regulates } \\
\text { VEGFR2 protecting against oxygen and } \\
\text { glucose deprivation (in vitro) } \\
\text { (Freitas-Andrade et al. 2008) } \\
\text { Knockout accelerates Wallerian peripheral } \\
\text { nerve degeneration (Chaballe et al. } \\
\text { 2011a) }\end{array}$ \\
\hline Liver & $\mathrm{ND}$ & $\begin{array}{l}\text { Knockout or aPlGF reduces portosystemic } \\
\text { collateral formation and portal pressure } \\
\text { in portal hypertension (Van Steenkiste } \\
\text { et al. 2009) } \\
\text { Knockout or aPlGF reduces angiogenesis, } \\
\text { arteriogenesis, inflammation, fibrosis, } \\
\text { and portal hypertension in liver cirrhosis } \\
\text { (Van Steenkiste et al. 2011) }\end{array}$ \\
\hline Gut/colon & ND & $\begin{array}{l}\text { Knockout aggravates disease course in acute } \\
\text { colitis (Hindryckx et al. 2010) }\end{array}$ \\
\hline Lung & $\begin{array}{l}\text { PlGF overexpression in lung causes } \\
\text { emphysema (Tsao et al. 2004) }\end{array}$ & $\begin{array}{l}\text { Knockout: protection against } \\
\text { elastase-induced emphysema (Cheng } \\
\text { et al. 2009) }\end{array}$ \\
\hline
\end{tabular}

ND, Not determined; aPlGF, neutralizing anti-PlGF antibodies; BM, bone marrow; EC endothelial cell; DRG, dorsal root ganglion; MSC, mesenchymal stem cell; PlGF, placental growth factor; RPE, retinal pigment epithelial; sFLT1, soluble FLT1; TAM, tumor-associated macrophage. 
M. Dewerchin and P. Carmeliet

Table 2. PIGF is expressed by various cell types

\begin{tabular}{|c|c|c|}
\hline Cell type & Inducers & References \\
\hline Endothelial cells & Hypoxia, VEGF, TGF & $\begin{array}{l}\text { Yonekura et al. 1999; Carmeliet et al. 2001; } \\
\text { Ota et al. 2002; Yao et al. 2005; Fujii et al. 2008; } \\
\text { Du et al. 2010; Jiang et al. } 2011\end{array}$ \\
\hline SMCs & $\mathrm{H}_{2} \mathrm{O}_{2}, \mathrm{BMP} 2$, AngII & $\begin{array}{l}\text { Yonekura et al. 1999; Tayade et al. 2007; Pan et al. } \\
\text { 2010; Shaw et al. } 2011\end{array}$ \\
\hline $\begin{array}{l}\text { Fibroblast-like cells: } \\
\text { fibroblasts, activated } \\
\text { HSC, synoviocytes }\end{array}$ & $\begin{array}{l}\text { Hypoxia (fibroblasts), } \\
\text { cytokines IL-1 } \beta \text { and } \\
\text { TNF (synoviocytes) }\end{array}$ & $\begin{array}{l}\text { Green et al. 2001; Yoo et al. 2009; } \\
\quad \text { Van Steenkiste et al. } 2011\end{array}$ \\
\hline $\begin{array}{l}\text { Leukocytes, lymphocytes, } \\
\text { TAMs }\end{array}$ & & $\begin{array}{l}\text { Luttun et al. 2002; Tayade et al. 2007; Rolny } \\
\text { et al. } 2011\end{array}$ \\
\hline Hepatocytes & & Van Steenkiste et al. 2011 \\
\hline $\begin{array}{l}\text { BM progenitors, erythroid } \\
\text { cells, MSC, stromal cells }\end{array}$ & $\begin{array}{l}\text { BMP-2 (MSCs), integrin/ } \\
\text { VCAM-1 (stroma }\end{array}$ & $\begin{array}{l}\text { Lyden et al. 2001; Hattori et al. 2002; Marrony et al. } \\
\text { 2003; Patel et al. 2010; Schmidt et al. } 2011\end{array}$ \\
\hline $\begin{array}{l}\text { Neuronal and supportive } \\
\text { cells: neurons, Schwann } \\
\text { cells, astrocytes }\end{array}$ & Hypoxia (astrocytes) & $\begin{array}{l}\text { Beck et al. 2002; Hayashi et al. 2003; } \\
\quad \text { Freitas-Andrade et al. 2008; Chaballe et al. } 2011 \mathrm{~b}\end{array}$ \\
\hline Cardiomyocytes & Hypoxia & Luttun et al. 2002; Torry et al. 2009 \\
\hline $\begin{array}{l}\text { Epithelial cells: RPE, } \\
\text { bronchial epithelial cells, } \\
\text { type II pneumocytes, } \\
\text { keratinocytes }\end{array}$ & $\begin{array}{l}\text { TGF- } \beta \text {, BMP4, light } \\
\text { (RPE), nitric oxide } \\
\text { (bronchial epithelial } \\
\text { cells) }\end{array}$ & $\begin{array}{l}\text { Failla et al. 2000; Cianfarani et al. 2006; Hollborn } \\
\text { et al. 2006; Miyamoto et al. 2007; Mohammed } \\
\text { et al. 2007; Verhaeghe et al. 2007; Kernt et al. } \\
\text { 2010; Akrami et al. 2011; Sands et al. } 2011\end{array}$ \\
\hline Osteogenic cells & & Coenegrachts et al. 2010 \\
\hline Chondrocytes & Cytokines (IL-1 $\beta$, TNF) & De Ceuninck et al. 2004 \\
\hline Tumor cells & Oncogenes & $\begin{array}{l}\text { Larcher et al. 2003; Parr et al. 2005; Wei et al. 2005; } \\
\text { Fischer et al. 2007; Bagley et al. } 2011\end{array}$ \\
\hline Thyrocytes & $\begin{array}{l}\text { Thyroid-stimulating } \\
\text { hormone }\end{array}$ & Viglietto et al. 1997; Efimenko et al. 2011 \\
\hline Adipose tissue-derived MSC & & Viglietto et al. 1997; Efimenko et al. 2011 \\
\hline
\end{tabular}

Cell types are listed with reported information on inducers of PlGF expression where available. AngII, Angiopoietin II; BMP, bone morphogenic protein; HSC, hepatic stellate cell; IL, interleukin; RPE, retinal pigment epithelial; MSC, mesenchymal stem cell; SMC, smooth muscle cell; TAM, tumor-associated macrophage; TGF, transforming growth factor; TNF, tumor necrosis factor.

involvement in several ischemic, inflammatory, or malignant pathologies, with attention to translational studies and clinical implications.

\section{DISEASES AGGRAVATED BY PIGF DEFICIENCY AND IMPROVED BY PIGF THERAPY}

\section{Ischemic Cardiovascular Disease}

Myocardial ischemia is a major cause of morbidity and mortality. After acute myocardial infarction (AMI), the viable cardiac tissue in the remote area and border zone undergoes hypertrophy in an effort to compensate for the ischemic muscle damage; if not supported by angiogenesis, this hypertrophy can lead to maladaptive decompensation (Shiojima et al. 2005). A role for PlGF in the response to cardiac ischemia is illustrated by findings that PlGF-deficient mice display reduced angiogenesis and inflammation in the border zone of the infarcted myocardium (Carmeliet et al. 2001). Conversely, PlGF gene or protein transfer in infarcted mice stimulates angiogenesis in the infarct border and vessel enlargement in the remote myocardium, improving vascular perfusion, cardiomyocyte hypertrophy, and cardiac recovery (Luttun et al. 2002; Roncal et al. 2008). Unlike systemic treatment with 
VEGF (Lee et al. 2000), PlGF treatment did not cause side effects of hypotension or edema formation (Luttun et al. 2002; Roncal et al. 2008). Similar results were obtained with intramyocardial delivery of recombinant PlGF in a rat model of ischemic cardiomyopathy (Kolakowski et al. 2006).

In accordance with these preclinical data, elevated serum levels of the PIGF trap sFLT1 seem to be an independent predictor of mortality in patients with suspected AMI (Hochholzer et al. 2011). Correlation studies in patients and mouse models indicate that cardiac expression of PlGF promotes wound healing after AMI, possibly by inducing mobilization of mononuclear cells and enhancing angiogenesis (Iwama et al. 2006). These data warrant further investigation of whether PlGF therapy may represent a valuable adjunct or alternative to current revascularization strategies for patients with ischemic heart disease.

However, clinical studies also reported correlations between elevated plasma PlGF levels and adverse cardiac outcome during long-term follow-up of patients with acute coronary syndromes, possibly reflecting ongoing inflammatory processes in the coronary vessel wall that may trigger cardiocascular events (Heeschen et al. 2004; Lenderink et al. 2006; Apple et al. 2007; Siervo et al. 2010). The latter is in line with findings that PlGF blockade slows down atherosclerotic progression in preclinical models (see below), warranting caution in PlGF treatment for cardiac disease.

\section{Limb Ischemia}

Gene inactivation studies revealed that collateral vessel growth and vascular perfusion in limb ischemia are impaired in PIGF-deficient mice (Carmeliet et al. 2001; Scholz et al. 2003; Gigante et al. 2006). Conversely, PlGF protein or gene administration enhances angiogenesis, collateral vessel formation, and blood flow in surgically induced limb ischemia in mice, resulting in improved performance in endurance tests (Luttun et al. 2002; Babiak et al. 2004). Similar effects were seen in limb ischemia in the rabbit (Pipp et al. 2003). The effect
PIGF: A Multitasking Disease-Restricted Cytokine

was due in part to smooth muscle cell growth, as well as activation and recruitment of mononuclear cells to the ischemic region (Luttun et al. 2002; Pipp et al. 2003). Endogenous PlGF is also essential for FGF-2-mediated recovery of blood flow in limb ischemia (Fujii et al. 2008).

\section{Nervous System}

In cerebral ischemia, PIGF is up-regulated in neurons and vascular cells. NRP-1 expression is also elevated in vessels while its ligand Sema3A is reduced, overall facilitating binding of PlGF (Beck et al. 2002). Intravenous delivery of PlGF-overexpressing mesenchymal stem cells (MSCs) to rats with surgically induced cerebral ischemia reduces lesion size, increases angiogenesis, and attenuates ischemia-induced functional deficits (Liu et al. 2006). PlGF also promotes the survival of cortical neurons in vitro under oxygen and glucose deprivation (Du et al. 2010). On the other side, PlGF deficiency renders astrocytes more resistant to oxygen and glucose deprivation in vitro (Freitas-Andrade et al. 2008). How these differential effects of PlGF in particular cell types regulate the overall outcome of cerebral ischemia remains to be further unraveled. In the peripheral nervous system, PlGF is detectable in axons of the sciatic nerve, and in Schwann cells after axotomy (Chaballe et al. 2011a). Knockout studies indicate that PlGF stimulates proliferation and migration of Schwann cells and promotes an inflammatory response by recruiting macrophages via up-regulation of MCP-1, essential for axonal regeneration (Chaballe et al. 2011a). PlGF also antagonizes chemo-repulsive effects of Sema3A on dorsal root ganglion neurons through NRP binding (Cheng et al. 2004). In contrast, no effect of PlGF deficiency was observed in the course of motoneuron degeneration in rodent models of ALS (P Carmeliet, unpubl.).

\section{Skin Wound Healing}

In the skin, PlGF expression is up-regulated during wound healing (Failla et al. 2000; Kagawa et al. 2009), and PlGF-deficient mice 
show delayed wound closure (Carmeliet et al. 2001). This finding is corroborated by results that PlGF gene or protein delivery in the skin stimulates angiogenesis, macrophage infiltration, granulation tissue formation, keratinocyte migration and healing of skin wounds in normal mice as well as in diabetic mice, which suffer impaired wound healing (Carmeliet et al. 2001; Cianfarani et al. 2006; Odorisio et al. 2006). Wound vascularization and healing are improved after treatment of skin wounds with dermal fibroblasts containing endothelial progenitor cells, presumably because these cells release PlGF (Hendrickx et al. 2010).

\section{Bone Fracture Repair}

Angiogenesis and inflammation are involved in bone fracture healing (Le et al. 2001; Carano and Filvaroff 2003). In a mouse model of semistabilized bone fracture healing, PlGF deficiency impairs healing, cartilage accumulation, angiogenesis, and inflammatory cell recruitment (Maes et al. 2006). In vitro and in vivo data suggest that PlGF contributes to the proliferation and osteogenic differentiation of mesenchymal progenitors, promotes cartilage turnover, and mediates remodeling of newly formed bone through stimulation of osteoclast differentiation (Maes et al. 2006).

\section{Colitis}

Inflammation is a key component of inflammatory bowel disease. In an acute colonic injury model, PlGF deficiency impairs mucosal angiogenesis, aggravates epithelial hypoxia, and worsens the disease outcome (Hindryckx et al. 2010). Notably, PlGF gene delivery improves healing of the inflamed colon (Hindryckx et al. 2010).

\section{Sepsis}

PlGF levels are elevated in preclinical animal models of sepsis (Yano et al. 2006). PlGF protects liver endothelial cells against septic injury, explaining why sepsis morbidity is increased following genetic or pharmacologic PlGF blockade (Yano et al. 2006, 2008). PlGF blockade in septic conditions should thus be considered with caution.

\section{Preeclampsia}

PlGF induces vasodilation of uterine, myometrial, mesenteric, and subcutaneous arteries. This effect is particularly pronounced in uterine arteries during pregnancy, suggesting that PlGF contributes to uterine vascular remodeling during pregnancy (Osol et al. 2008). These findings are consistent with data that utero-placental hypoperfusion and hypertension in preeclampsia patients reduce PIGF plasma levels, because of excessive release of sFLT1, causing endothelial dysfunction in maternal tissue (Foidart et al. 2009; Furuya et al. 2011). Whether PlGF delivery offers novel therapeutic opportunities for preecclampsia remains to be determined.

\section{DISEASES WITH IMPROVED OUTCOME FOLLOWING PIGF BLOCKADE}

\section{Ocular Neovascularization}

Retinal neovascularization and macular edema, resulting from blood-retinal barrier (BRB) breakdown, are major causes of visual loss in diabetic patients (Morello 2007). PlGF is elevated in the vitreous and retina of diabetic patients and animals (Khaliq et al. 1998; Miyamoto et al. 2007; Kowalczuk et al. 2011). Intraocular delivery of high amounts of PlGF gene or protein in healthy rodents causes retinal vessel disorganization, dilatation, microaneurysm formation, sprouting, rupture of the retinal barrier, and edema, all reminiscent of the changes seen in early diabetic retinopathy (Miyamoto et al. 2007; Kowalczuk et al. 2011).

Choroidal neovascularization $(\mathrm{CNV})$ in patients with the wet form of age-related macular degeneration (AMD) is another prevalent cause of visual loss, especially in the elderly (Mitchell et al. 2010). PlGF is elevated in human AMD and mouse models of laser-induced CNV (Rakic et al. 2003; Huang et al. 2011), whereas PlGF gene deficiency in mice reduces experimental CNV (Rakic et al. 2003). Current treatment of CNV in human AMD by VEGF blockade offers visual improvement but requires intravitreal injection and can increase the risk of stroke, ischemic heart disease, and adverse ocular events (Mitchell et al. 2010). Genetic 
blockage of PlGF or pharmacological inhibition of PlGF by systemic administration of an anti-PlGF mAb inhibits laser-induced CNV in mice (Van de Veire et al. 2010). Combination therapy with an anti-PlGF and anti-VEGFR2 $\mathrm{mAb}$ is also more effective than monotherapy with anti-PlGF mAb alone. Anti-PlGF not only inhibits angiogenesis and vascular leakiness, but also improves vessel maturation and, unlike anti-VEGFR2 mAb, attenuates ocular inflammation (Van de Veire et al. 2010). Systemic anti-PlGF mAb may thus offer new treatment perspectives for ocular angiogenic disorders.

\section{Atherosclerosis}

Loss of PlGF in mice delays atherosclerotic lesion development and inhibits macrophage infiltration, whereas local PlGF gene delivery aggravates atherosclerotic plaque formation in hypercholesterolemic rabbits (Khurana et al. 2005). PlGF is increased in atherosclerotic aortas in apoE $\mathrm{E}^{-/-}$mouse models (Roncal et al. 2010). Pharmacological neutralization of PlGF in preclinical mouse models of aggressive atherosclerosis with vulnerable plaques, characterized by inflammatory cell infiltration and limited collagen maturation, slows down plaque development in early phases of atherogenesis but is largely ineffective in more advanced stages. The effect is accompanied by a reduced infiltration of macrophages and T-cells and a lower expression of the adhesion molecule VCAM-1, involved in the recruitment of circulating monocytes to the subendothelial space (Roncal et al. 2010). Thus, anti-PlGF mAb phenocopies the genetic data by reducing early atherogenesis and inflammatory cell infiltration in the lesion.

\section{Arthritis}

Rheumatoid arthritis (RA) is a chronic polyarticular inflammation that affects small joints and is characterized by synovial inflammation and formation of a pannus that destroys articular structures. This pannus is highly vascularized, and numerous factors promote angiogenesis in the inflamed joints (Paleolog 2002). Among them, PlGF induces the secretion of VEGF and
PIGF: A Multitasking Disease-Restricted Cytokine

proinflammatory cytokines from mononuclear cells (Ballara et al. 2001; Yoo et al. 2009). Deficiency of PlGF suppresses RA disease development and progression in mouse models of arthritic joint disease (Yoo et al. 2009). In addition, administration of soluble FLT1 or an FLT1-neutralizing antibody or peptide reduces disease severity and joint destruction (Bottomley et al. 2000; Miotla et al. 2000; Luttun et al. 2002; Yoo et al. 2009).

\section{Liver Cirrhosis}

PlGF is also a disease candidate in liver cirrhosis. PlGF levels are increased in cirrhotic patients and in a CCl4-induced cirrhosis model in mice (Van Steenkiste et al. 2011). In the absence of PlGF, liver inflammation, fibrosis, vessel growth and remodeling, and portal hypertension are all less severe in cirrhotic mice. Furthermore, in mice with established cirrhosis, PlGF blockade attenuates disease progression (Van Steenkiste et al. 2011). In cirrhotic rodents, PlGF is markedly up-regulated in hepatic stellate cells, known key players in fibrogenesis. In vitro, PlGF induces ERK1/2 signaling and promotes chemotaxis and proliferation of hepatic stellate cells (Van Steenkiste et al. 2011). Intriguingly, PlGF prolongs the activation of PDGF-R $\alpha$ and EGFR, possibly because of a transactivation of these receptors by FLT-1. Together, these data suggest a role for PlGF in cirrhosis and illustrate the therapeutic potential of PlGF blockade to attenuate cirrhotic disease. Notably, PlGF accelerates the progression of hepatocellular carcinoma (HCC), a cancer developing frequently in cirrhotic livers (see below).

\section{Cutaneous Delayed-Type Hypersensitivity}

PlGF is up-regulated in skin inflammation. In a mouse model of cutaneous delayed-type hypersensitivity, keratinocyte-specific overexpression of PlGF increases the inflammatory response and causes pronounced vascular enlargement (Oura et al. 2003). Opposite phenotypes are observed in PlGF-deficient mice (Oura et al. 2003). 
Obesity

Obesity is a major risk factor of metabolic syndrome and ischemic cardiovascular disease. In mouse models of nutritional obesity, PlGF deficiency impairs fat tissue growth partly because of reduced angiogenesis. Anti-PlGF treatment reduces de novo fat pad formation, however, without affecting adipose tissue development, suggesting a role of PlGF in the early stages of adipogenesis (Lijnen et al. 2006). On the other hand, PIGF deficiency reduces the fraction of brown adipocytes while stimulating white adipocyte hypertrophy in mice fed a high-fat diet, changes that promote insulin resistance and hyperinsulinemia (Hemmeryckx et al. 2008).

\section{Pulmonary Emphysema}

Increased PlGF levels are observed in patients with chronic obstructive pulmonary disease (COPD) (Cheng et al. 2008). Enforced overexpression of PlGF in lungs of mice causes emphysema due to type II pneumocyte death (Tsao et al. 2004), but PlGF deficiency protects mice against elastase-induced pulmonary emphysema (Cheng et al. 2009). These phenotypes suggest a role of PlGF in the inflammatory process during emphysema, even though the precise role and mechanism of PIGF in pulmonary homeostasis remain to be unraveled.

Besides the aforementioned disease settings, solid and hematologic cancer is emerging as an additional disorder that could benefit from PlGF blockade. We discuss the evidence and controversies in the next sections.

\section{PIGF IN CANCER AND METASTASIS}

An "angiogenic switch" promotes tumor growth (Carmeliet and Jain 2011a; Hanahan and Weinberg 2011). In contrast to healthy vessels, tumor vessels have a distorted architecture and display an irregular lining of discontinuous, misshaped endothelial cells, overall impairing perfusion, facilitating tumor cell dissemination, and promoting cancer invasion (Carmeliet and Jain 2011b). Blockade of VEGF signaling offers clinical benefit in several cancer types, but the survival benefit is often limited (in the order of months), and numerous patients develop resistance (Ferrara 2009; Carmeliet and Jain 2011a). Normalizing tumor vessels is emerging as another novel paradigm to reduce metastasis and enhance antitumor chemotherapy (Carmeliet and Jain 2011b).

\section{PIGF in Tumor Pathogenesis}

PlGF mRNA and protein levels correlate with tumor stage, invasion and/or metastasis, tumor recurrence, and inversely with survival in several although not all tumor types (Fischer et al. 2008; Bagley et al. 2011). Exceptions include colon and lung carcinoma, where PlGF expression is low because of epigenetic silencing (Xu and Jain 2007). Not only can the tumor cells themselves produce PIGF, but also most types of stromal cells, including endothelial cells, smooth muscle cells, pericytes, cancerassociated fibroblasts (CAFs), tumor-associated macrophages (TAMs), and inflammatory cells (Yonekura et al. 1999; Carmeliet et al. 2001; Luttun et al. 2002; Fischer et al. 2007; Bagley et al. 2011; Rolny et al. 2011). Moreover, recent studies document a tumor cell $\leftrightarrow$ stroma cross talk, in which tumor cells can "educate" stroma cells to produce PlGF. This was shown for bone marrow stromal cells in preclinical models of bone metastasis of breast cancer and of chronic myeloid leukemia (Coenegrachts et al. 2010; Schmidt et al. 2011). PlGF thereby creates a fertile microenvironmental soil for the seeding tumor cells to foster their survival and expansive growth.

PlGF can promote tumor growth via various distinct mechanisms (Fig. 2). One of them is by stimulating vessel growth and maturation (Adini et al. 2002; Li et al. 2006; Fischer et al. 2007; Van de Veire et al. 2010). Noteworthy, pharmacological or genetic PlGF blockade also promotes vessel normalization (Van de Veire et al. 2010; Rolny et al. 2011). In spontaneous HCC models, PlGF blockade partially restored the abnormally enlarged intercapillary distance, reduced vessel tortuosity, improved vessel patency and tumor oxygenation, and normalized sinusoidal capillarization (Fig. 3) (Van de Veire 


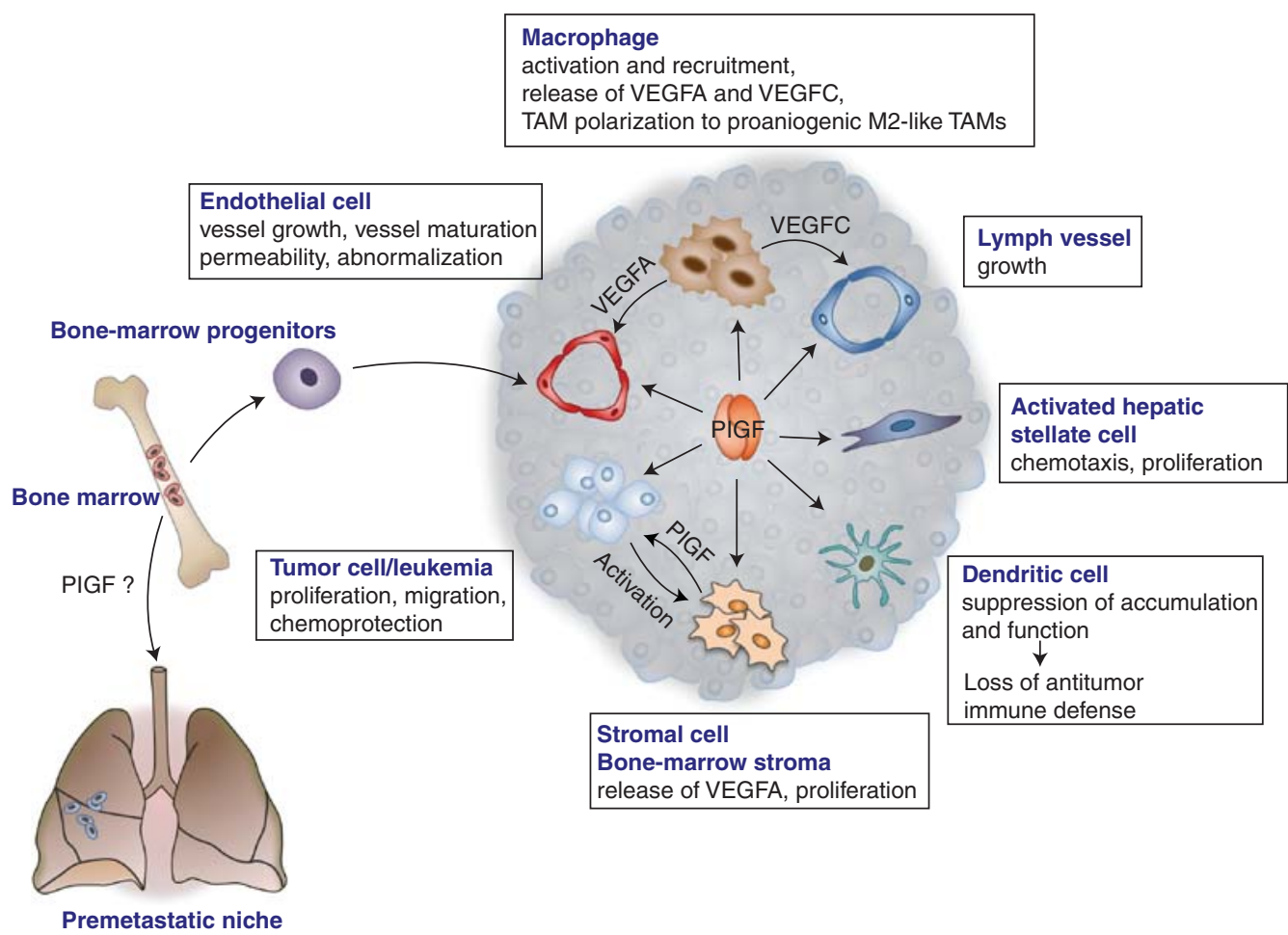

Figure 2. Roles of PlGF in cancer and metastasis. PlGF affects various cellular components and processes in the tumor. It affects angiogenesis by promoting proliferation and migration of endothelial cells, maturation of the vessels by recruiting smooth muscle cells, mobilization of vasculogenic bone-marrow progenitors, and recruitment of macrophages, which produce additional angiogenic and lymphangiogenic factors. PlGF also enhances the "disorganization" of tumor vessels, characterized by an irregular appearance and discontinuous endothelial lining, including "sinusoidal capillarization" in HCC (see also Fig. 3). PlGF also promotes the proliferation and migration of activated hepatic stellate cells in HCC and liver fibrosis. PlGF reduces dendritic cell accumulation and function, thereby suppressing antitumor immune defense responses. PlGF directly stimulates proliferation of tumor cells, which cross talk to and activate stromal cells to produce PlGF (see also Fig. 4). PlGF was also implicated in the mobilization of bone marrow-derived progenitor cells to the "premetastic niche," although conflicting data have been reported. TAM, Tumor-associated macrophage; VEGFA, vascular endothelial growth factor A; VEGFC, vascular endothelial growth factor C.

et al. 2010). Because hypoxia is a driving force for HCC growth (Wu et al. 2007), vessel normalization by PlGF blockade slows down HCC progression. In transplantable tumor models, loss of stromal PlGF normalizes tumor vessels (without altering vascular density), thereby improving tumor oxygenation and responses to chemotherapy, while reducing metastasis (Rolny et al. 2011). In contrast, another study reported vessel normalization in tumors with enforced PlGF overexpression (Hedlund et al. 2009). These apparently divergent results can, however, be reconciled because enforced PIGF overexpression is known to favor the formation of PlGF/ VEGF heterodimers at the expense of angiogenic VEGF homodimers that are known to promote vessel disorganization.

PIGF also stimulates inflammatory cell recruitment and activation (Kerber et al. 2008; Ding et al. 2010; Van de Veire et al. 2010; Laurent et al. 2011). It also induces polarization of TAMs to an M2-like proangiogenic phenotype, thereby promoting tumor vessel disorganization (Rolny et al. 2011). PlGF promotes 


\section{Dewerchin and P. Carmeliet}
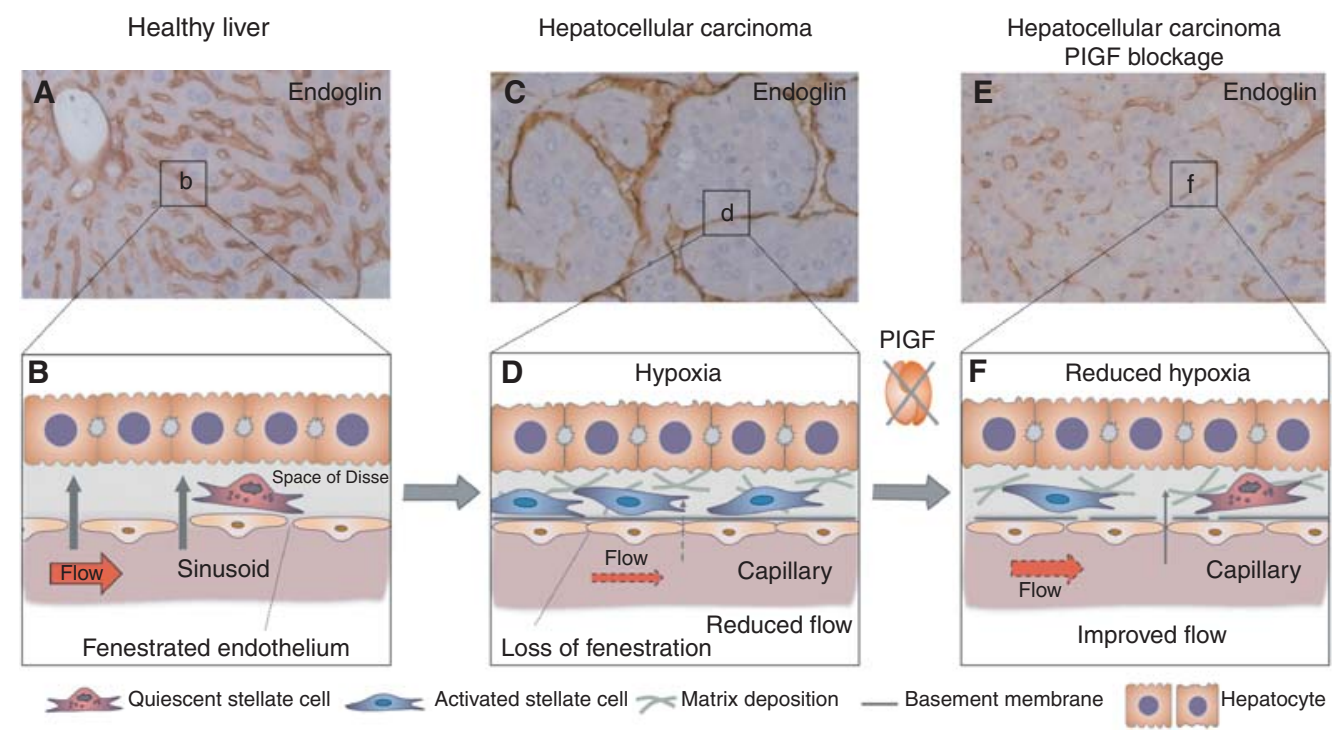

Figure 3. Role of PlGF in sinusoidal disorganization in HCC. $(A, B)$ In healthy liver, the hepatic microvascular units, the sinusoids (visualized by endoglin immunostaining in $A$ ), are characterized by a porous fenestrated endothelial lining and absence of a basement membrane, facilitating oxygen and metabolic exchange between the bloodstream and the hepatocytes; the latter are separated from the sinusoids by the perisinusoidal space (space of Disse), where quiescent hepatic stellate cells reside $(B) .(C, D)$ In hepatocellular carcinoma, sinusoids undergo "capillarization," characterized by loss of fenestration, increased numbers of activated stellate cells that deposit matrix and release angiogenic factors, change of shape and size of the capillarized sinusoids to more tortuous vessels, and lumen loss in a fraction of the capillaries. These changes result in impaired blood flow (red arrow in $D$ ) along with reduced oxygen transfer from the blood to the liver parenchyma (gray arrow in $D$ ), resulting in increased hypoxia, which further promotes tumor cell proliferation resulting in enlarged intercapillary distances $(C)$. $(E, F)$ PlGF blockage by gene silencing or by inhibition with neutralizing antibody partially prevented this disorganization of hepatic sinusoids. The abnormal tortuous appearance, abnormal size, and loss of lumenization of the sinusoids were attenuated $(E)$, and sinusoidal "capillarization" was reduced $(F)$. This partial "normalization" by PlGF blockage functionally improved tissue oxygenation and reduced proliferation of HCC cells (Van de Veire et al. 2010; Rolny et al. 2011).

growth and migration of tumor cells and protects them against cytotoxic injury by chemotherapeutics (Casalou et al. 2007; Fischer et al. 2007; Taylor et al. 2010; Schmidt et al. 2011). It also suppresses antitumor immune responses by reducing dendritic cell accumulation and function (Lin et al. 2007; Rolny et al. 2011). Furthermore, PlGF/FLT1 promotes mobilization of bone marrow-derived progenitors to future metastatic sites of lung carcinoma, thereby forming a "premetastatic niche" for disseminating metastatic tumor cells (Kaplan et al. 2005, 2009). However, the precise involvement of PlGF/FLT1 in the premetastatic niche formation remains to be further resolved because divergent effects of FLT1 inhibition have been reported (Kaplan et al. 2009; Duda and Jain 2010).

Of note, plasma levels of PlGF are often increased in cancer patients receiving $\operatorname{VEGF}(\mathrm{R})$ inhibition therapy, raising the question of whether PlGF is a factor contributing to the acquistion of "resistance" (evasive escape) against anti-VEGF therapy (Bergers and Hanahan 2008; Jain et al. 2009; Bagley et al. 2011; Carmeliet and Jain 2011a). Experimental models using human tumor xenografts in mice show elevated murine PlGF (but not human PlGF) levels following anti-VEGF treatment, suggesting that PlGF up-regulation by VEGF blockade is at least in part a host reponse (Bagley et al. 2011). Consistent herewith, inhibition or 
PIGF: A Multitasking Disease-Restricted Cytokine

deletion of host-derived murine PlGF reduces growth of human xenograft or syngeneic tumors (Fischer et al. 2007; Van de Veire et al. 2010; Rolny et al. 2011; Yao et al. 2011). The importance of PlGF in the response of the tumor to VEGF inhibition may, however, be tumor type-specific or context-dependent, as VEGF(R)-inhibitor treatment did not result in an up-regulation of PlGF mRNA or protein in several preclinical tumor models (Bais et al. 2010).

\section{PIGF: A Target for Anticancer Therapy?}

Phenocopying the effects seen upon PlGF blockade by gene inactivation or RNA interference (Carmeliet et al. 2001; Van de Veire et al. 2010; Laurent et al. 2011), pharmacological PlGF inhibition by neutralizing antibodies (anti-PlGF antibodies 5D11D4, 3C7A5) or by PlGF/FLT1 peptide antagonists reduced tumor growth, angiogenesis, lymphangiogenesis, inflammation, and metastasis in different ectopically and orthotopically implanted tumors in mouse models, in the absence of adverse side effects (Fischer et al. 2007; Taylor and Goldenberg 2007; Coenegrachts et al. 2010; Bagley et al. 2011). PlGF is also diffusely expressed in medulloblastoma, the most common malignant brain tumor of childhood, and genetic and pharmacologic inhibition of PlGF leads to growth delay and regression of medulloblastoma models in mice as well (Snuderl et al. 2010). Of note, PlGF neutralization by genetic deficiency, anti-PlGF mAb treatment, or small interfering RNA (siRNA) mediated silencing also reduced the growth of spontaneously arising tumor models, including carcinogen-induced skin papilloma or HCC, as well as a transgenic oncogene-based HCC model (Van de Veire et al. 2010).

In several tumor models, the effects on tumor growth and the underlying mechanisms observed with anti-PlGF treatment phenocopied the effects seen with genetic PlGF deficiency (Van de Veire et al. 2010). For instance, normalization of tumor blood vessels has been observed in the HCC model upon genetic or pharmacological PlGF blockade (Van de Veire et al. 2010; Rolny et al. 2011). In addition, combined anti-VEGFR2/anti-PlGF mAb delivery regimens were superior to the anti-PlGF monotherapies, and anti-PlGF mAb was able to replace anti-VEGFR2 mAb partially without loss of efficacy (Fischer et al. 2007). The 5D11D4 anti-PlGF mAb also blocked the growth of tumors resistant to anti-VEGFR2 blockage (monoclonal antibody DC101 or a VEGF-specific trap, soluble VEGFR2, also termed sFLK1) (Davidoff et al. 2002; Fischer et al. 2007). PlGF blockade also enhanced the effect of chemotherapy in preclinical tumor models and improved vessel normalization and perfusion (Fischer et al. 2007; Rolny et al. 2011). Neutralizing antibodies against human PlGF similarly reduced tumor growth in human xenograft models (Van de Veire et al. 2010; Xu et al. 2010). A humanized anti-human PlGF $\mathrm{mAb}$ has entered phase II trials for clinical evaluation of an anticancer benefit.

Nevertheless, not all studies documented antitumor efficacy by blocking PlGF. For instance, not all antibodies with neutralizing capacity in in vitro assays proved to be effective in vivo, either alone as monotherapy or as combination therapy with anti-VEGF mAb, nor did all tumor types respond to anti-PlGF mAb treatment (Bais et al. 2010; Van de Veire et al. 2010; Yao et al. 2011). The precise reasons for these discrepancies remain to be further uncovered (Bais et al. 2010; Van de Veire et al. 2010), but may in part depend on the expression of FLT1 by the tumor cells (Yao et al. 2011). A recent study confirmed that PlGF blockade slowed down chronic myeloid leukemia progression in part by preventing direct growth stimulatory effects of PlGF on leukemia cells, but genetic studies using tyrosine kinase-dead VEGFR1 mice also showed that PlGF signaling in the stromal compartment contributed to leukemia progression (Schmidt et al. 2011). The latter notion is consistent with numerous findings that PlGF affects stromal cells in nononcology conditions. The relative effect of PlGF on tumor versus stromal cells requires further study.

Also worth mentioning are observations that a soluble FLT1 agent (trapping VEGF, PlGF, and VEGF-B) was not more effective in blocking tumor growth than an anti-VEGF 
mAb (Shojaei et al. 2007; Bais et al. 2010). To complicate matters further, divergent tumor growth phenotypes have been reported when implanting tumors in a tyrosine kinase-dead FLT1 mutant mouse model, with some studies reporting a reduction in tumor growth/metastasis (Hiratsuka et al. 2001, 2002; Kerber et al. 2008; Van de Veire et al. 2010; Schmidt et al. 2011) and others showing no effect (Dawson et al. 2009; Bais et al. 2010; Muramatsu et al. 2010). Presumably, the importance of PlGF/ FLT1 is context-dependent. Another issue relates to the role of PlGF to angiogenic escape mechanisms of the tumor under anti-VEGF therapy. Indeed, in a recent study using an agent blocking both VEGF and PIGF, reduction of tumor growth was observed while PlGF levels were increased (Bagley et al. 2011). Further exploration is required to resolve these issues.

\section{HEMATOLOGICAL HOMEOSTASIS AND MALIGNANCIES}

PlGF promotes the recruitment and differentiation of bone marrow progenitors and regulates hematopoietic reconstitution after myelosuppression (Hattori et al. 2002; Luttun et al. 2002; Carlo-Stella et al. 2007; Loges et al. 2009). PlGF is released by erythroid cells and plasma PlGF is elevated in patients with sickle cell disease (SCD), correlating with hemolysis (Patel et al. 2008; Brittain et al. 2010). PlGF levels are further increased in SCD patients with pulmonary hypertension (Brittain et al. 2010). Consistent herewith, overexpression of PlGF in erythroid cells of healthy mice induces pulmonary hypertension via elevated endothelial production of the vasoconstrictor endothelin-1, which is elevated in SCD patients as well (Patel et al. 2008; Sundaram et al. 2010). The protease inhibitor PAI-1 is similarly elevated in SCD patients and mice. In vitro, PlGF induces PAI-1 expression in endothelial cells and monocytes, in part via HIF- $1 \alpha$-mediated transcriptional regulation and miRNA-regulated posttranscriptional mechanisms, and PlGF deficiency in SCD mice reduces PAI-1 levels, suggesting that PlGF may promote a prothrombotic state in SCD (Patel et al. 2010, 2011).
Further data also indicate that erythroid PlGF aggravates inflammation and airway hyperreactivity in SCD via production of proinflammatory leukotriene (Patel et al. 2009; Patel and Kalra 2010).

In vitro, PlGF stimulates the growth of acute lymphoblastic leukemic (ALL) and acute myeloid leukemia (AML) cells, and FLT1 is expressed by human chronic myeloid leukemia (CML) cells (Ikai et al. 2005; Fragoso et al. 2006). However, the role of PIGF in leukemogenesis in vivo remained largely unexplored, and antiangiogenic therapy using $\operatorname{VEGF}(\mathrm{R})$ blockers has not met the anticipated success as seen in solid malignancies. A recent study documented that PlGF levels in the bone marrow plasma or peripheral blood correlate with BCR-ABL1 ${ }^{+}$leukemia load in CML mice and are elevated in CML patients upon disease progression (Schmidt et al. 2011). PlGF produced by the host stroma accelerates disease progression of BCR-ABL1 ${ }^{+}$leukemia in mouse models of CML. When cocultured with CML cells, bone marrow stromal cells elevated their production of PlGF, a process relying on NF- $\kappa \mathrm{B}$ pathway signaling (Fig. 4). By stimulating bone marrow angiogenesis and promoting the growth and glycolytic metabolism of CML cells, PlGF thus appears to create a fertile soil for the CML cells, besides affecting tumor cells themselves.

Furthermore, genetic loss of host PlGF or systemic inhibition with anti-PlGF mAb prolonged the survival of CML mice. Interestingly, PlGF stimulated various signaling pathways in parallel with BCR-ABL1 signaling. The ability of PlGF to stimulate BCR-ABL1-independent signaling in combination with its effects on the CML tumor stroma in the bone marrow likely explains why anti-PlGF mAb treatment added to the anti-CML activity of imatinib in imatinib-sensitive CML mice and prolonged survival in an imatinib-resistant CML model (Schmidt et al. 2011). The ability of malignant cells to induce PlGF in stromal cells was not restricted to CML but was observed with other leukemogenic tumor cells as well, warranting further exploration of targeting the BM stroma or blocking $\mathrm{BM}$ angiogenesis in leukemogenic disease (Schmidt et al. 2011). 
PIGF: A Multitasking Disease-Restricted Cytokine

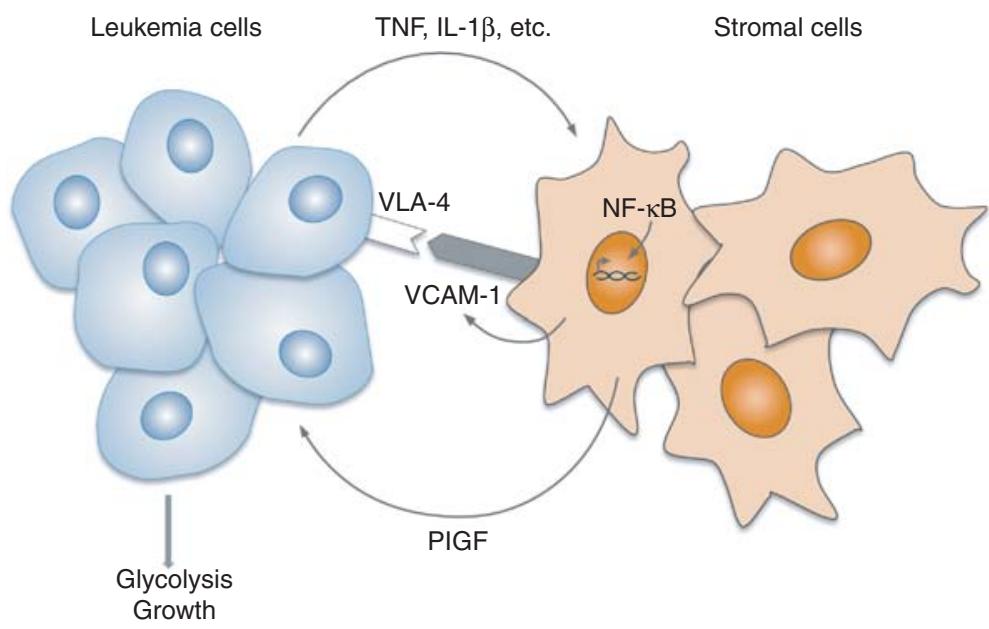

Figure 4. Bidirectional cross talk between leukemia and bone marrow stromal cells. In chronic myeloid leukemia $(\mathrm{CML})$, tumor cells "educate" bone marrow stromal cells to produce PlGF. This induction involves NF-кB activation in the stromal cells and requires leukemia cell/stromal cell contact, which is in part mediated by VLA-4/ VCAM-1 interaction. VLA-4/VCAM-1 interaction is reported to activate NF- $\mathrm{KB}$ (Zohlnhofer et al. 2000), and NF- $\kappa B$, in turn, up-regulates VCAM-1 (Rajan et al. 2008), suggesting a positive feedback loop reinforcing $\mathrm{VLA}^{+}$CML cell binding to the VCAM-1-expressing stromal cells, thereby ensuring PlGF production. Stromal cell-derived PIGF then promotes proliferation and metabolism of the CML cells. Overall, PlGF creates a fertile microenvironmental soil for the seeding tumor cells to foster cancer cell survival and expansive growth (Schmidt et al. 2011).

\section{CONCLUDING REMARKS}

Altogether, the genetic data available to date provide evidence for a role of PlGF in multiple phenotypic traits. A paramount feature is that PlGF appears to be dispensable for development and normal health and that modulation of PlGF expression or action in pathological conditions does not interfere with normal physiological processes. The challenge for the future is to further define the actions of PlGF in normal physiology and disease conditions and to explore if this target can be clinically exploited in an effective, safe manner. Another challenge will be to reconcile the conflicting data obtained by pharmacological PlGF blockade and the more robust PlGF-knockout data.

\section{ACKNOWLEDGMENTS}

We thank L. Notebaert and A. Truyens for help with the illustrations. The authors are supported by funding from the FWO-Vlaanderen (FWO G.0651.08N); Stichting Emmanuel van der Schueren (Belgium); long-term structural Methusalem funding by the Flemish Government, Concerted Research Activities, Belgium (grant GOA2006/11); Belgian Science Policy (grant IUAP06/30); and a Susan G. Komen for the Cure research grant (KG070498).

P. Carmeliet is named as inventor on patents, claiming subject matter that is partially based on results summarized in this review. The patents are licensed/submitted, which may result in a royalty payment to $\mathrm{P}$. Carmeliet.

\section{REFERENCES}

Adini A, Kornaga T, Firoozbakht F, Benjamin LE. 2002. Placental growth factor is a survival factor for tumor endothelial cells and macrophages. Cancer Res 62: 2749-2752.

Akrami H, Soheili ZS, Sadeghizadeh M, Ahmadieh H, Rezaeikanavi M, Samiei S, Khalooghi K. 2011. PlGF gene knockdown in human retinal pigment epithelial cells. Graefes Arch Clin Exp Ophthalmol 249: 537-546.

Apple FS, Pearce LA, Chung A, Ler R, Murakami MM. 2007. Multiple biomarker use for detection of adverse events in patients presenting with symptoms suggestive of acute coronary syndrome. Clin Chem 53: 874-881. 
Autiero M, Waltenberger J, Communi D, Kranz A, Moons L, Lambrechts D, Kroll J, Plaisance S, De Mol M, Bono F, et al. 2003. Role of PlGF in the intra- and intermolecular cross talk between the VEGF receptors Flt1 and Flk1. Nat Med 9: 936-943.

Babiak A, Schumm AM, Wangler C, Loukas M, Wu J, Dombrowski S, Matuschek C, Kotzerke J, Dehio C, Waltenberger J. 2004. Coordinated activation of VEGFR-1 and VEGFR-2 is a potent arteriogenic stimulus leading to enhancement of regional perfusion. Cardiovasc Res 61: 789-795.

Bagley RG, Ren Y, Weber W, Yao M, Kurtzberg L, Pinckney J, Bangari D, Nguyen C, Brondyk W, Kaplan J, et al. 2011. Placental growth factor upregulation is a host response to antiangiogenic therapy. Clin Cancer Res 17: 976-988.

Bais C, Wu X, Yao J, Yang S, Crawford Y, McCutcheon K, Tan C, Kolumam G, Vernes JM, Eastham-Anderson J, et al. 2010. PlGF blockade does not inhibit angiogenesis during primary tumor growth. Cell 141: 166-177.

Ballara S, Taylor PC, Reusch P, Marme D, Feldmann M, Maini RN, Paleolog EM. 2001. Raised serum vascular endothelial growth factor levels are associated with destructive change in inflammatory arthritis. Arthritis Rheum 44: 2055-2064.

Barleon B, Siemeister G, Martiny-Baron G, Weindel K, Herzog C, Marme D. 1997. Vascular endothelial growth factor up-regulates its receptor fms-like tyrosine kinase 1 (FLT-1) and a soluble variant of FLT-1 in human vascular endothelial cells. Cancer Res 57: 5421-5425.

Beck H, Acker T, Puschel AW, Fujisawa H, Carmeliet P, Plate KH. 2002. Cell type-specific expression of neuropilins in an MCA-occlusion model in mice suggests a potential role in post-ischemic brain remodeling. J Neuropathol Exp Neurol 61: 339-350.

Bellik L, Vinci MC, Filippi S, Ledda F, Parenti A. 2005. Intracellular pathways triggered by the selective FLT-1-agonist placental growth factor in vascular smooth muscle cells exposed to hypoxia. Br J Pharmacol 146: 568-575.

Bergers G, Hanahan D. 2008. Modes of resistance to antiangiogenic therapy. Nat Rev Cancer 8: 592-603.

Bjorndahl M, Cao R, Eriksson A, Cao Y. 2004. Blockage of VEGF-induced angiogenesis by preventing VEGF secretion. Circ Res 94: 1443-1450.

Bottomley MJ, Webb NJ, Watson CJ, Holt L, Bukhari M, Denton J, Freemont AJ, Brenchley PE. 2000. Placenta growth factor (PlGF) induces vascular endothelial growth factor (VEGF) secretion from mononuclear cells and is co-expressed with VEGF in synovial fluid. Clin Exp Immunol 119: 182-188.

Brittain JE, Hulkower B, Jones SK, Strayhorn D, De Castro L, Telen MJ, Orringer EP, Hinderliter A, Ataga KI. 2010. Placenta growth factor in sickle cell disease: Association with hemolysis and inflammation. Blood 115: 2014-2020.

Cai J, Wu L, Qi X, Shaw L, Li Calzi S, Caballero S, Jiang WG Vinores SA, Antonetti D, Ahmed A, et al. 2011. Placenta growth factor-1 exerts time-dependent stabilization of adherens junctions following VEGF-induced vascular permeability. PLoS One 6: e18076. doi: 10.1371/ journal.pone.0018076.

Cao Y, Chen H, Zhou L, Chiang MK, Anand-Apte B, Weatherbee JA, Wang Y, Fang F, Flanagan JG, Tsang ML. 1996a. Heterodimers of placenta growth factor/vascular endothelial growth factor. Endothelial activity, tumor cell expression, and high affinity binding to Flk-1/ KDR. J Biol Chem 271: 3154-3162.

Cao Y, Linden P, Shima D, Browne F, Folkman J. 1996b. In vivo angiogenic activity and hypoxia induction of heterodimers of placenta growth factor/vascular endothelial growth factor. J Clin Invest 98: 2507-2511.

Cao Y, Ji WR, Qi P, Rosin A, Cao Y. 1997. Placenta growth factor: Identification and characterization of a novel isoform generated by RNA alternative splicing. Biochem Biophys Res Commun 235: 493-498.

Carano RA, Filvaroff EH. 2003. Angiogenesis and bone repair. Drug Discov Today 8: 980-989.

Carlo-Stella C, Di Nicola M, Longoni P, Cleris L, Lavazza C, Milani R, Milanesi M, Magni M, Pace V, Colotta F, et al. 2007. Placental growth factor-1 potentiates hematopoietic progenitor cell mobilization induced by granulocyte colony-stimulating factor in mice and nonhuman primates. Stem Cells 25: 252-261.

Carmeliet P, Jain RK. 2011a. Molecular mechanisms and clinical applications of angiogenesis. Nature 473: 298-307.

Carmeliet P, Jain RK. 2011b. Principles and mechanisms of vessel normalization for cancer and other angiogenic diseases. Nat Rev Drug Discov 10: 417-427.

Carmeliet P, Moons L, Luttun A, Vincenti V, Compernolle V, De Mol M, Wu Y, Bono F, Devy L, Beck H, et al. 2001. Synergism between vascular endothelial growth factor and placental growth factor contributes to angiogenesis and plasma extravasation in pathological conditions. Nat Med 7: 575-583.

Casalou C, Fragoso R, Nunes JF, Dias S. 2007. VEGF/PLGF induces leukemia cell migration via P38/ERK1/2 kinase pathway, resulting in Rho GTPases activation and caveolae formation. Leukemia 21: 1590-1594.

Chaballe L, Close P, Sempels M, Delstanche S, Fanielle J, Moons L, Carmeliet P, Schoenen J, Chariot A, Franzen R. 2011a. Involvement of placental growth factor in Wallerian degeneration. Glia 59: 379-396.

Chaballe L, Schoenen J, Franzen R. 2011b. Placental growth factor: A tissue modelling factor with therapeutic potentials in neurology? Acta Neurol Belg 111: 10-17.

Cheng L, Jia H, Lohr M, Bagherzadeh A, Holmes DI, Selwood D, Zachary I. 2004. Anti-chemorepulsive effects of vascular endothelial growth factor and placental growth factor-2 in dorsal root ganglion neurons are mediated via neuropilin-1 and cyclooxygenase-derived prostanoid production. J Biol Chem 279: 30654-30661.

Cheng SL, Wang HC, Yu CJ, Yang PC. 2008. Increased expression of placenta growth factor in COPD. Thorax 63: 500-506.

Cheng SL, Wang HC, Yu CJ, Tsao PN, Carmeliet P, Cheng SJ, Yang PC. 2009. Prevention of elastase-induced emphysema in placenta growth factor knock-out mice. Respir Res 10: $115-125$.

Cianfarani F, Zambruno G, Brogelli L, Sera F, Lacal PM, Pesce M, Capogrossi MC, Failla CM, Napolitano M, Odorisio T. 2006. Placenta growth factor in diabetic wound healing: Altered expression and therapeutic potential. Am J Pathol 169: 1167-1182. 
Cindrova-Davies T, Sanders DA, Burton GJ, CharnockJones DS. 2011. Soluble FLT1 sensitizes endothelial cells to inflammatory cytokines by antagonizing VEGF receptor-mediated signalling. Cardiovasc Res 89: 671-679.

Clauss M, Weich H, Breier G, Knies U, Rockl W, Waltenberger J, Risau W. 1996. The vascular endothelial growth factor receptor Flt-1 mediates biological activities. Implications for a functional role of placenta growth factor in monocyte activation and chemotaxis. J Biol Chem 271: 17629-17634.

Coenegrachts L, Maes C, Torrekens S, Van Looveren R, Mazzone M, Guise TA, Bouillon R, Stassen JM, Carmeliet P, Carmeliet G. 2010. Anti-placental growth factor reduces bone metastasis by blocking tumor cell engraftment and osteoclast differentiation. Cancer Res 70: 6537-6547.

Davidoff AM, Nathwani AC, Spurbeck WW, Ng CY, Zhou J, Vanin EF. 2002. rAAV-mediated long-term liver-generated expression of an angiogenesis inhibitor can restrict renal tumor growth in mice. Cancer Res 62: 3077-3083.

Dawson MR, Duda DG, Chae SS, Fukumura D, Jain RK. 2009. VEGFR1 activity modulates myeloid cell infiltration in growing lung metastases but is not required for spontaneous metastasis formation. PLoS One 4: e6525. doi: 10.1371/journal.pone.0006525.

De Ceuninck F, Dassencourt L, Anract P. 2004. The inflammatory side of human chondrocytes unveiled by antibody microarrays. Biochem Biophys Res Commun 323: 960-969.

Depoix C, Tee MK, Taylor RN. 2011. Molecular regulation of human placental growth factor $(P l G F)$ gene expression in placental villi and trophoblast cells is mediated via the protein kinase A pathway. Reprod Sci 18: 219-228.

Ding Y, Huang Y, Song N, Gao X, Yuan S, Wang X, Cai H, Fu Y, Luo Y. 2010. NFAT1 mediates placental growth factorinduced myelomonocytic cell recruitment via the induction of TNF- $\alpha$. J Immunol 184: 2593-2601.

DiPalma T, Tucci M, Russo G, Maglione D, Lago CT, Romano A, Saccone S, Della Valle G, De Gregorio L, Dragani TA, et al. 1996. The placenta growth factor gene of the mouse. Mamm Genome 7: 6-12.

DiSalvo J, Bayne ML, Conn G, Kwok PW, Trivedi PG, Soderman DD, Palisi TM, Sullivan KA, Thomas KA. 1995. Purification and characterization of a naturally occurring vascular endothelial growth factor $\bullet$ placenta growth factor heterodimer. J Biol Chem 270: 7717-7723.

Du H, Li P, Pan Y, Li W, Hou J, Chen H, Wang J, Tang H. 2010. Vascular endothelial growth factor signaling implicated in neuroprotective effects of placental growth factor in an in vitro ischemic model. Brain Res 1357: 1-8.

Duda DG, Jain RK. 2010. Premetastatic lung "niche": Is vascular endothelial growth factor receptor 1 activation required? Cancer Res 70: 5670-5673.

Efimenko A, Starostina E, Kalinina N, Stolzing A. 2011. Angiogenic properties of aged adipose derived mesenchymal stem cells after hypoxic conditioning. J Transl Med 9: 10. doi: 10.1186/1479-5876-9-10.

Eriksson A, Cao R, Pawliuk R, Berg SM, Tsang M, Zhou D, Fleet C, Tritsaris K, Dissing S, Leboulch P, et al. 2002. Placenta growth factor-1 antagonizes VEGF-induced angiogenesis and tumor growth by the formation of functionally inactive PlGF-1/VEGF heterodimers. Cancer Cell 1: 99-108.
PIGF: A Multitasking Disease-Restricted Cytokine

Failla CM, Odorisio T, Cianfarani F, Schietroma C, Puddu P, Zambruno G. 2000. Placenta growth factor is induced in human keratinocytes during wound healing. Invest Dermatol 115: 388-395.

Feeney SA, Simpson DA, Gardiner TA, Boyle C, Jamison P, Stitt AW. 2003. Role of vascular endothelial growth factor and placental growth factors during retinal vascular development and hyaloid regression. Invest Ophthalmol Vis Sci 44: 839-847.

Ferrara N. 2009. VEGF-A: A critical regulator of blood vessel growth. Eur Cytokine Netw 20: 158-163.

Fiedler J, Leucht F, Waltenberger J, Dehio C, Brenner RE. 2005. VEGF-A and PlGF-1 stimulate chemotactic migration of human mesenchymal progenitor cells. Biochem Biophys Res Commun 334: 561-568.

Fischer C, Jonckx B, Mazzone M, Zacchigna S, Loges S, Pattarini L, Chorianopoulos E, Liesenborghs L, Koch M, De Mol M, et al. 2007. Anti-PlGF inhibits growth of VEGF(R)-inhibitor-resistant tumors without affecting healthy vessels. Cell 131: 463-475.

Fischer C, Mazzone M, Jonckx B, Carmeliet P. 2008. FLT1 and its ligands VEGFB and PlGF: Drug targets for antiangiogenic therapy? Nat Rev Cancer 8: 942-956.

Foidart JM, Schaaps JP, Chantraine F, Munaut C, Lorquet S. 2009. Dysregulation of anti-angiogenic agents (sFlt-1, PLGF, and sEndoglin) in preeclampsia-A step forward but not the definitive answer. J Reprod Immunol 82: 106-111.

Fragoso R, Pereira T, Wu Y, Zhu Z, Cabecadas J, Dias S. 2006. VEGFR-1 (FLT-1) activation modulates acute lymphoblastic leukemia localization and survival within the bone marrow, determining the onset of extramedullary disease. Blood 107: 1608-1616.

Freitas-Andrade M, Carmeliet P, Stanimirovic DB, Moreno M. 2008. VEGFR-2-mediated increased proliferation and survival in response to oxygen and glucose deprivation in PlGF knockout astrocytes. J Neurochem 107: 756-767.

Frysz-Naglak D, Fryc B, Klimacka-Nawrot E, Mazurek U, Suchecka W, Kajor M, Kurek J, Stadnicki A. 2011. Expression, localization and systemic concentration of vascular endothelial growth factor (VEGF) and its receptors in patients with ulcerative colitis. Int Immunopharmacol 11: $220-225$.

Fujii T, Yonemitsu Y, Onimaru M, Inoue M, Hasegawa M, Kuwano H, Sueishi K. 2008. VEGF function for upregulation of endogenous PIGF expression during FGF-2mediated therapeutic angiogenesis. Atherosclerosis 200: 51-57.

Furuya M, Kurasawa K, Nagahama K, Kawachi K, Nozawa A, Takahashi T, Aoki I. 2011. Disrupted balance of angiogenic and antiangiogenic signalings in preeclampsia. $J$ Pregnancy 2011: 123717.

Gargioli C, Coletta M, De Grandis F, Cannata SM, Cossu G. 2008. PlGF-MMP-9-expressing cells restore microcirculation and efficacy of cell therapy in aged dystrophic muscle. Nat Med 14: 973-978.

Gerber HP, Condorelli F, Park J, Ferrara N. 1997. Differential transcriptional regulation of the two vascular endothelial growth factor receptor genes. Flt-1, but not Flk-1/KDR, is up-regulated by hypoxia. J Biol Chem 272: 2365923667. 
M. Dewerchin and P. Carmeliet

Gigante B, Tarsitano M, Cimini V, De Falco S, Persico MG. 2004. Placenta growth factor is not required for exercise-induced angiogenesis. Angiogenesis 7: 277-284.

Gigante B, Morlino G, Gentile MT, Persico MG, De Falco S. 2006. $\mathrm{Plgf}^{-/-} \mathrm{eNos}^{-/-}$mice show defective angiogenesis associated with increased oxidative stress in response to tissue ischemia. FASEB J 20: 970-972.

Green CJ, Lichtlen P, Huynh NT, Yanovsky M, Laderoute KR, Schaffner W, Murphy BJ. 2001. Placenta growth factor gene expression is induced by hypoxia in fibroblasts: A central role for metal transcription factor-1. Cancer Res 61: 2696-2703.

Hagberg CE, Falkevall A, Wang X, Larsson E, Huusko J, Nilsson I, van Meeteren LA, Samen E, Lu L, Vanwildemeersch M, et al. 2010. Vascular endothelial growth factor B controls endothelial fatty acid uptake. Nature 464: 917-921.

Hanahan D, Weinberg RA. 2011. Hallmarks of cancer: The next generation. Cell 144: 646-674.

Hattori K, Heissig B, Wu Y, Dias S, Tejada R, Ferris B, Hicklin DJ, Zhu Z, Bohlen P, Witte L, et al. 2002. Placental growth factor reconstitutes hematopoiesis by recruiting VEGFR $1^{+}$stem cells from bone-marrow microenvironment. Nat Med 8: 841-849.

Hauser S, Weich HA. 1993. A heparin-binding form of placenta growth factor (PlGF-2) is expressed in human umbilical vein endothelial cells and in placenta. Growth Factors 9: 259-268.

Hayashi T, Noshita N, Sugawara T, Chan PH. 2003. Temporal profile of angiogenesis and expression of related genes in the brain after ischemia. J Cereb Blood Flow Metab 23: 166-180.

Hedlund EM, Hosaka K, Zhong Z, Cao R, Cao Y. 2009 Malignant cell-derived PlGF promotes normalization and remodeling of the tumor vasculature. Proc Natl Acad Sci 106: 17505-17510.

Heeschen C, Dimmeler S, Fichtlscherer S, Hamm CW, Berger J, Simoons ML, Zeiher AM. 2004. Prognostic value of placental growth factor in patients with acute chest pain. JAMA 291: 435-441.

Hemmeryckx B, van Bree R, Van Hoef B, Vercruysse L, Lijnen HR, Verhaeghe J. 2008. Adverse adipose phenotype and hyperinsulinemia in gravid mice deficient in placental growth factor. Endocrinology 149: 2176-2183.

Hendrickx B, Verdonck K, Van den Berge S, Dickens S, Eriksson E, Vranckx JJ, Luttun A. 2010. Integration of blood outgrowth endothelial cells in dermal fibroblast sheets promotes full thickness wound healing. Stem Cells 28: $1165-1177$.

Hindryckx P, Waeytens A, Laukens D, Peeters H, Van Huysse J, Ferdinande L, Carmeliet P, De Vos M. 2010. Absence of placental growth factor blocks dextran sodium sulfate-induced colonic mucosal angiogenesis, increases mucosal hypoxia and aggravates acute colonic injury. Lab Invest 90: 566-576.

Hiratsuka S, Maru Y, Okada A, Seiki M, Noda T, Shibuya M. 2001. Involvement of Flt-1 tyrosine kinase (vascular endothelial growth factor receptor-1) in pathological angiogenesis. Cancer Res 61: 1207-1213.

Hiratsuka S, Nakamura K, Iwai S, Murakami M, Itoh T, Kijima H, Shipley JM, Senior RM, Shibuya M. 2002. MMP9 induction by vascular endothelial growth factor receptor-1 is involved in lung-specific metastasis. Cancer Cell 2: 289-300.

Hochholzer W, Reichlin T, Stelzig C, Hochholzer K, Meissner J, Breidthardt T, Reiter M, Duehsler B, Freidank H, Winkler K, et al. 2011. Impact of soluble fms-like tyrosine kinase- 1 and placental growth factor serum levels for risk stratification and early diagnosis in patients with suspected acute myocardial infarction. Eur Heart $J$ 32: 326-335.

Hollborn M, Tenckhoff S, Seifert M, Kohler S, Wiedemann P, Bringmann A, Kohen L. 2006. Human retinal epithelium produces and responds to placenta growth factor. Graefes Arch Clin Exp Ophthalmol 244: 732-741.

Huang XX, McCaughan GW, Shackel NA, Gorrell MD. 2007. Up-regulation of proproliferative genes and the ligand/ receptor pair placental growth factor and vascular endothelial growth factor receptor 1 in hepatitis $\mathrm{C}$ cirrhosis. Liver Int 27: 960-968.

Huang H, Shen J, Vinores SA. 2011. Blockade of VEGFR1 and 2 suppresses pathological angiogenesis and vascular leakage in the eye. PLoS One 6: e21411. doi: 10.1371/ journal.pone.0021411.

Ikai T, Miwa H, Shikami M, Hiramatsu A, Tajima E, Yamamoto H, Imai N, Hattori A, Nishii K, Miura K, et al. 2005. Placenta growth factor stimulates the growth of Philadelphia chromosome positive acute lymphoblastic leukemia cells by both autocrine and paracrine pathways. Eur J Haematol 75: 273-279.

Iwama H, Uemura S, Naya N, Imagawa K, Takemoto Y, Asai O, Onoue K, Okayama S, Somekawa S, Kida Y, et al. 2006. Cardiac expression of placental growth factor predicts the improvement of chronic phase left ventricular function in patients with acute myocardial infarction. J Am Coll Cardiol 47: 1559-1567.

Jain RK, Duda DG, Willett CG, Sahani DV, Zhu AX, Loeffler JS, Batchelor TT, Sorensen AG. 2009. Biomarkers of response and resistance to antiangiogenic therapy. Nat Rev Clin Oncol 6: 327-338.

Jiang X, Khan MA, Tian W, Beilke J, Natarajan R, Kosek J, Yoder MC, Semenza GL, Nicolls MR. 2011. Adenovirusmediated HIF- $1 \alpha$ gene transfer promotes repair of mouse airway allograft microvasculature and attenuates chronic rejection. J Clin Invest 121: 2336-2349.

Kagawa S, Matsuo A, Yagi Y, Ikematsu K, Tsuda R, Nakasono I. 2009. The time-course analysis of gene expression during wound healing in mouse skin. Leg Med (Tokyo) 11: $70-75$.

Kaplan RN, Riba RD, Zacharoulis S, Bramley AH, Vincent L, Costa C, MacDonald DD, Jin DK, Shido K, Kerns SA, et al. 2005. VEGFR1-positive haematopoietic bone marrow progenitors initiate the pre-metastatic niche. Nature 438: $820-827$.

Kaplan RN, Riba RD, Zacharoulis S, Bramley AH, Vincent L, Costa C, MacDonald DD, Jin DK, Shido K, Kerns SA, et al. 2009. Reply. Nature 461: E5-E6.

Kendall RL, Thomas KA. 1993. Inhibition of vascular endothelial cell growth factor activity by an endogenously encoded soluble receptor. Proc Natl Acad Sci 90: 10705-10709.

Kendall RL, Wang G, Thomas KA. 1996. Identification of a natural soluble form of the vascular endothelial growth 
PIGF: A Multitasking Disease-Restricted Cytokine

factor receptor, FLT-1, and its heterodimerization with KDR. Biochem Biophys Res Commun 226: 324-328.

Kerber M, Reiss Y, Wickersheim A, Jugold M, Kiessling F, Heil M, Tchaikovski V, Waltenberger J, Shibuya M, Plate $\mathrm{KH}$, et al. 2008. Flt-1 signaling in macrophages promotes glioma growth in vivo. Cancer Res 68: 7342-7351.

Kernt M, Neubauer AS, Liegl RG, Hirneiss C, Alge CS, Wolf A, Ulbig MW, Kampik A. 2010. Sorafenib prevents human retinal pigment epithelium cells from lightinduced overexpression of VEGF, PDGF and PlGF. $\mathrm{Br} J$ Ophthalmol 94: 1533-1539.

Khaliq A, Foreman D, Ahmed A, Weich H, Gregor Z, McLeod D, Boulton M. 1998. Increased expression of placenta growth factor in proliferative diabetic retinopathy. Lab Invest 78: 109-116.

Khurana R, Moons L, Shafi S, Luttun A, Collen D, Martin JF, Carmeliet P, Zachary IC. 2005. Placental growth factor promotes atherosclerotic intimal thickening and macrophage accumulation. Circulation 111: 2828-2836.

Kolakowski S Jr, Berry MF, Atluri P, Grand T, Fisher O, Moise MA, Cohen J, Hsu V, Woo YJ. 2006. Placental growth factor provides a novel local angiogenic therapy for ischemic cardiomyopathy. J Card Surg 21: 559-564.

Kowalczuk L, Touchard E, Omri S, Jonet L, Klein C, Valamanes F, Berdugo M, Bigey P, Massin P, Jeanny JC, et al. 2011. Placental growth factor contributes to microvascular abnormalization and blood-retinal barrier breakdown in diabetic retinopathy. PLoS One 6: e17462. doi: 10.1371/journal.pone.0017462.

Landgren E, Schiller P, Cao Y, Claesson-Welsh L. 1998. Placenta growth factor stimulates MAP kinase and mitogenicity but not phospholipase $\mathrm{C}-\boldsymbol{\gamma}$ and migration of endothelial cells expressing Flt 1. Oncogene 16:359-367.

Larcher F, Franco M, Bolontrade M, Rodriguez-Puebla M, Casanova L, Navarro M, Yancopoulos G, Jorcano JL, Conti CJ. 2003. Modulation of the angiogenesis response through Ha-ras control, placenta growth factor, and angiopoietin expression in mouse skin carcinogenesis. Mol Carcinog 37: 83-90.

Laurent J, Faes-Van't Hull E, Touvrey C, Kuonen F, Lan Q, Lorusso G, Doucey MA, Ciarloni L, Imaizumi N, Alghisi GC, et al. 2011. Proangiogenic factor PlGF programs $\mathrm{CD}_{11} \mathrm{~b}^{+}$myelomonocytes in breast cancer during differentiation of their hematopoietic progenitors. Cancer Res 71: 3781-3791.

Le AX, Miclau T, Hu D, Helms JA. 2001. Molecular aspects of healing in stabilized and non-stabilized fractures. $J$ Orthop Res 19: 78-84.

Lee RJ, Springer ML, Blanco-Bose WE, Shaw R, Ursell PC, Blau HM. 2000. VEGF gene delivery to myocardium: Deleterious effects of unregulated expression. Circulation 102: 898-901.

Lenderink T, Heeschen C, Fichtlscherer S, Dimmeler S, Hamm CW, Zeiher AM, Simoons ML, Boersma E. 2006. Elevated placental growth factor levels are associated with adverse outcomes at four-year follow-up in patients with acute coronary syndromes. J Am Coll Cardiol 47: 307-311.

Li B, Sharpe EE, Maupin AB, Teleron AA, Pyle AL, Carmeliet P, Young PP. 2006. VEGF and PIGF promote adult vasculogenesis by enhancing EPC recruitment and vessel formation at the site of tumor neovascularization. FASEB J 20: $1495-1497$.

Lijnen HR, Christiaens V, Scroyen I, Voros G, Tjwa M, Carmeliet P, Collen D. 2006. Impaired adipose tissue development in mice with inactivation of placental growth factor function. Diabetes 55: 2698-2704.

Lin YL, Liang YC, Chiang BL. 2007. Placental growth factor down-regulates type $1 \mathrm{~T}$ helper immune response by modulating the function of dendritic cells. J Leukoc Biol 82: $1473-1480$.

Liu H, Honmou O, Harada K, Nakamura K, Houkin K, Hamada H, Kocsis JD. 2006. Neuroprotection by PlGF gene-modified human mesenchymal stem cells after cerebral ischaemia. Brain 129: 2734-2745.

Loges S, Schmidt T, Carmeliet P. 2009. "Antimyeloangiogenic" therapy for cancer by inhibiting PlGF. Clin Cancer Res 15: 3648-3653.

Luttun A, Tjwa M, Moons L, Wu Y, Angelillo-Scherrer A, Liao F, Nagy JA, Hooper A, Priller J, De Klerck B, et al. 2002. Revascularization of ischemic tissues by PlGF treatment, and inhibition of tumor angiogenesis, arthritis and atherosclerosis by anti-Flt1. Nat Med 8: 831-840.

Lyden D, Hattori K, Dias S, Costa C, Blaikie P, Butros L, Chadburn A, Heissig B, Marks W, Witte L, et al. 2001. Impaired recruitment of bone-marrow-derived endothelial and hematopoietic precursor cells blocks tumor angiogenesis and growth. Nat Med 7: 1194-1201.

Maes C, Coenegrachts L, Stockmans I, Daci E, Luttun A, Petryk A, Gopalakrishnan R, Moermans K, Smets N, Verfaillie $\mathrm{CM}$, et al. 2006. Placental growth factor mediates mesenchymal cell development, cartilage turnover, and bone remodeling during fracture repair. J Clin Invest 116: $1230-1242$.

Maglione D, Guerriero V, Viglietto G, Delli-Bovi P, Persico MG. 1991. Isolation of a human placenta cDNA coding for a protein related to the vascular permeability factor. Proc Natl Acad Sci 88: 9267-9271.

Malik AK, Baldwin ME, Peale F, Fuh G, Liang WC, Lowman H, Meng G, Ferrara N, Gerber HP. 2006. Redundant roles of VEGF-B and PIGF during selective VEGF-A blockade in mice. Blood 107: 550-557.

Marcellini M, De Luca N, Riccioni T, Ciucci A, Orecchia A, Lacal PM, Ruffini F, Pesce M, Cianfarani F, Zambruno G, et al. 2006. Increased melanoma growth and metastasis spreading in mice overexpressing placenta growth factor. Am J Pathol 169: 643-654.

Marrony S, Bassilana F, Seuwen K, Keller H. 2003. Bone morphogenetic protein 2 induces placental growth factor in mesenchymal stem cells. Bone 33: 426-433.

Migdal M, Huppertz B, Tessler S, Comforti A, Shibuya M, Reich R, Baumann H, Neufeld G. 1998. Neuropilin-1 is a placenta growth factor-2 receptor. J Biol Chem 273: 22272-22278.

Miotla J, Maciewicz R, Kendrew J, Feldmann M, Paleolog E. 2000. Treatment with soluble VEGF receptor reduces disease severity in murine collagen-induced arthritis. Lab Invest 80: 1195-1205.

Mitchell P, Korobelnik JF, Lanzetta P, Holz FG, Prunte C, Schmidt-Erfurth U, Tano Y, Wolf S. 2010. Ranibizumab (Lucentis) in neovascular age-related macular degeneration: Evidence from clinical trials. Br J Ophthalmol 94: $2-13$. 
Miyamoto N, de Kozak Y, Jeanny JC, Glotin A, Mascarelli F, Massin P, BenEzra D, Behar-Cohen F. 2007. Placental growth factor-1 and epithelial haemato-retinal barrier breakdown: Potential implication in the pathogenesis of diabetic retinopathy. Diabetologia 50: 461-470.

Mohammed KA, Nasreen N, Tepper RS, Antony VB. 2007. Cyclic stretch induces PIGF expression in bronchial airway epithelial cells via nitric oxide release. Am J Physiol Lung Cell Mol Physiol 292: L559-L566.

Morello CM. 2007. Etiology and natural history of diabetic retinopathy: An overview. Am J Health Syst Pharm 64: S3-S7.

Munaut C, Lorquet S, Pequeux C, Blacher S, Berndt S, Frankenne F, Foidart JM. 2008. Hypoxia is responsible for soluble vascular endothelial growth factor receptor-1 (VEGFR-1) but not for soluble endoglin induction in villous trophoblast. Hum Reprod 23: 1407-1415.

Murakami T, Imada Y, Kawamura M, Takahashi T, Fujita Y, Sato E, Yoshitomi H, Sunada Y, Nakamura A. 2011. Placental growth factor-2 gene transfer by electroporation restores diabetic sensory neuropathy in mice. Exp Neurol 227: 195-202.

Muramatsu M, Yamamoto S, Osawa T, Shibuya M. 2010. Vascular endothelial growth factor receptor-1 signaling promotes mobilization of macrophage lineage cells from bone marrow and stimulates solid tumor growth. Cancer Res 70: 8211-8221.

Neufeld G, Kessler O, Herzog Y. 2002. The interaction of Neuropilin-1 and Neuropilin-2 with tyrosine-kinase receptors for VEGF. Adv Exp Med Biol 515: 81-90.

Odorisio T, Cianfarani F, Failla CM, Zambruno G. 2006. The placenta growth factor in skin angiogenesis. J Dermatol Sci 41: 11-19.

Onoue K, Uemura S, Takeda Y, Somekawa S, Iwama H, Imagawa K, Nishida T, Morikawa Y, Takemoto Y, Asai O, et al. 2009. Reduction of circulating soluble fms-like tyrosine kinase- 1 plays a significant role in renal dysfunction-Associated aggravation of atherosclerosis. Circulation 120: $2470-2477$.

Osol G, Celia G, Gokina N, Barron C, Chien E, Mandala M, Luksha L, Kublickiene K. 2008. Placental growth factor is a potent vasodilator of rat and human resistance arteries. Am J Physiol Heart Circ Physiol 294: H1381-H1387.

Ota T, Fujii M, Sugizaki T, Ishii M, Miyazawa K, Aburatani H, Miyazono K. 2002. Targets of transcriptional regulation by two distinct type I receptors for transforming growth factor- $\beta$ in human umbilical vein endothelial cells. J Cell Physiol 193: 299-318.

Oura H, Bertoncini J, Velasco P, Brown LF, Carmeliet P, Detmar M. 2003. A critical role of placental growth factor in the induction of inflammation and edema formation. Blood 101: 560-567.

Paleolog EM. 2002. Angiogenesis in rheumatoid arthritis. Arthritis Res 4: S81-S90.

Pan P, Fu H, Zhang L, Huang H, Luo F, Wu W, Guo Y, Liu X. 2010. Angiotensin II upregulates the expression of placental growth factor in human vascular endothelial cells and smooth muscle cells. BMC Cell Biol 11: 36. doi: 10.1186/1471-2121-11-36.

Park JE, Chen HH, Winer J, Houck KA, Ferrara N. 1994. Placenta growth factor. Potentiation of vascular endothelial growth factor bioactivity, in vitro and in vivo, and high affinity binding to Flt-1 but not to Flk-1/KDR. J Biol Chem 269: 25646-25654.

Parr C, Watkins G, Boulton M, Cai J, Jiang WG. 2005. Placenta growth factor is over-expressed and has prognostic value in human breast cancer. Eur $J$ Cancer 41: 2819-2827.

Patel N, Kalra VK. 2010. Placenta growth factor-induced early growth response 1 (Egr-1) regulates hypoxia-inducible factor- $1 \alpha$ (HIF- $1 \alpha)$ in endothelial cells. J Biol Chem 285: 20570-20579.

Patel N, Gonsalves CS, Malik P, Kalra VK. 2008. Placenta growth factor augments endothelin-1 and endothelin-B receptor expression via hypoxia-inducible factor- $1 \alpha$. Blood 112: 856-865.

Patel N, Gonsalves CS, Yang M, Malik P, Kalra VK. 2009. Placenta growth factor induces 5-lipoxygenase-activating protein to increase leukotriene formation in sickle cell disease. Blood 113: 1129-1138.

Patel N, Sundaram N, Yang M, Madigan C, Kalra VK, Malik P. 2010. Placenta growth factor (PIGF), a novel inducer of plasminogen activator inhibitor-1 (PAI-1) in sickle cell disease (SCD). J Biol Chem 285: 16713-16722.

Patel N, Tahara SM, Malik P, Kalra VK. 2011. Involvement of miR-30c and miR-301a in immediate induction of plasminogen activator inhibitor-1 by placental growth factor in human pulmonary endothelial cells. Biochem J 434: 473-482.

Persico MG, Vincenti V, DiPalma T. 1999. Structure, expression and receptor-binding properties of placenta growth factor (PlGF). Curr Top Microbiol Immunol 237: 31-40.

Pipp F, Heil M, Issbrucker K, Ziegelhoeffer T, Martin S, van den Heuvel J, Weich H, Fernandez B, Golomb G, Carmeliet P, et al. 2003. VEGFR-1-selective VEGF homologue PlGF is arteriogenic: evidence for a monocyte-mediated mechanism. Circ Res 92: 378-385.

Rafii S, Avecilla S, Shmelkov S, Shido K, Tejada R, Moore MA, Heissig B, Hattori K. 2003. Angiogenic factors reconstitute hematopoiesis by recruiting stem cells from bone marrow microenvironment. Ann NY Acad Sci 996: 49-60.

Rajan S, Ye J, Bai S, Huang F, Guo YL. 2008. NF-кB, but not p38 MAP kinase, is required for TNF- $\alpha$-induced expression of cell adhesion molecules in endothelial cells. J Cell Biochem 105: 477-486.

Rakic JM, Lambert V, Devy L, Luttun A, Carmeliet P, Claes C, Nguyen L, Foidart JM, Noel A, Munaut C. 2003. Placental growth factor, a member of the VEGF family, contributes to the development of choroidal neovascularization. Invest Ophthalmol Vis Sci 44: 3186-3193.

Rolny C, Mazzone M, Tugues S, Laoui D, Johansson I, Coulon C, Squadrito ML, Segura I, Li X, Knevels E, et al. 2011. HRG inhibits tumor growth and metastasis by inducing macrophage polarization and vessel normalization through downregulation of PlGF. Cancer Cell 19: 31-44.

Roncal C, Buysschaert I, Chorianopoulos E, Georgiadou M, Meilhac O, Demol M, Michel JB, Vinckier S, Moons L, Carmeliet P. 2008. Beneficial effects of prolonged systemic administration of PlGF on late outcome of post-ischaemic myocardial performance. J Pathol 216: 236-244.

Roncal C, Buysschaert I, Gerdes N, Georgiadou M, Ovchinnikova O, Fischer C, Stassen JM, Moons L, Collen D, De 
Bock K, et al. 2010. Short-term delivery of anti-PlGF antibody delays progression of atherosclerotic plaques to vulnerable lesions. Cardiovasc Res 86: 29-36.

Roy H, Bhardwaj S, Babu M, Jauhiainen S, Herzig KH, Bellu AR, Haisma HJ, Carmeliet P, Alitalo K, Yla-Herttuala S. 2005. Adenovirus-mediated gene transfer of placental growth factor to perivascular tissue induces angiogenesis via upregulation of the expression of endogenous vascular endothelial growth factor-A. Hum Gene Ther 16: $1422-1428$.

Sands M, Howell K, Costello CM, McLoughlin P. 2011. Placenta growth factor and vascular endothelial growth factor B expression in the hypoxic lung. Respir Res 12: 17. doi: 10.1186/1465-9921-12-17.

Sawano A, Iwai S, Sakurai Y, Ito M, Shitara K, Nakahata T, Shibuya M. 2001. Flt-1, vascular endothelial growth factor receptor 1 , is a novel cell surface marker for the lineage of monocyte-macrophages in humans. Blood 97: $785-791$.

Schmidt T, Kharabi Masouleh B, Loges S, Cauwenberghs S, Fraisl P, Maes C, Jonckx B, De Keersmaecker K, Kleppe M, Tjwa M, et al. 2011. Loss or inhibition of stromal-derived PlGF prolongs survival of mice with imatinib-resistant Bcr-Abl1 ${ }^{+}$leukemia. Cancer Cell 19: 740-753.

Scholz D, Elsaesser H, Sauer A, Friedrich C, Luttun A, Carmeliet P, Schaper W. 2003. Bone marrow transplantation abolishes inhibition of arteriogenesis in placenta growth factor (PlGF) $)^{-/-}$mice. J Mol Cell Cardiol 35: 177-184.

Schomber T, Kopfstein L, Djonov V, Albrecht I, Baeriswyl V, Strittmatter K, Christofori G. 2007. Placental growth factor-1 attenuates vascular endothelial growth factorA-dependent tumor angiogenesis during $\beta$ cell carcinogenesis. Cancer Res 67: 10840-10848.

Selvaraj SK, Giri RK, Perelman N, Johnson C, Malik P, Kalra VK. 2003. Mechanism of monocyte activation and expression of proinflammatory cytochemokines by placenta growth factor. Blood 102: 1515-1524.

Shaw JH, Xiang L, Shah A, Yin W, Lloyd PG. 2011. Placenta growth factor expression is regulated by hydrogen peroxide in vascular smooth muscle cells. Am J Physiol Cell Physiol 300: C349-C355.

Shibuya M. 2006. Vascular endothelial growth factor receptor-1 (VEGFR-1/Flt-1): A dual regulator for angiogenesis. Angiogenesis 9: 225-231.

Shih SC, Ju M, Liu N, Smith LE. 2003. Selective stimulation of VEGFR-1 prevents oxygen-induced retinal vascular degeneration in retinopathy of prematurity. J Clin Invest 112: $50-57$.

Shiojima I, Sato K, Izumiya Y, Schiekofer S, Ito M, Liao R, Colucci WS, Walsh K. 2005. Disruption of coordinated cardiac hypertrophy and angiogenesis contributes to the transition to heart failure. J Clin Invest 115: 21082118.

Shojaei F, Wu X, Malik AK, Zhong C, Baldwin ME, Schanz S, Fuh G, Gerber HP, Ferrara N. 2007. Tumor refractoriness to anti-VEGF treatment is mediated by $\mathrm{CD} 11 \mathrm{~b}^{+} \mathrm{Gr} 1^{+}$ myeloid cells. Nat Biotechnol 25: 911-920.

Siervo M, Ruggiero D, Sorice R, Nutile T, Aversano M, Stephan BC, Ciullo M. 2010. Angiogenesis and biomarkers of cardiovascular risk in adults with metabolic syndrome. J Intern Med 268: 338-347.
PIGF: A Multitasking Disease-Restricted Cytokine

Snuderl M, Kirkpatrick ND, Walsh E, Chung E, Kamoun W, Peterson T, Munn LL, Duda DG, Fukumura D, Carmeliet P, et al. 2010. Inhibition of placental growth factor (PIGF) leads to regression of medulloblastoma. In Proceedings of the 101st Annual Meeting of the American Association for Cancer Research, 2010 Apr 17-21. AACR, Washington, DC.

Sundaram N, Tailor A, Mendelsohn L, Wansapura J, Wang X, Higashimoto T, Pauciulo MW, Gottliebson W, Kalra VK, Nichols WC, et al. 2010. High levels of placenta growth factor in sickle cell disease promote pulmonary hypertension. Blood 116: 109-112.

Suzuki H, Ohkuchi A, Matsubara S, Takei Y, Murakami M, Shibuya M, Suzuki M, Sato Y. 2009. Effect of recombinant placental growth factor 2 on hypertension induced by full-length mouse soluble fms-like tyrosine kinase 1 adenoviral vector in pregnant mice. Hypertension 54: 1129-1135.

Tarallo V, Vesci L, Capasso O, Esposito MT, Riccioni T, Pastore L, Orlandi A, Pisano C, De Falco S. 2010. A placental growth factor variant unable to recognize vascular endothelial growth factor (VEGF) receptor-1 inhibits VEGFdependent tumor angiogenesis via heterodimerization. Cancer Res 70: 1804-1813.

Tayade C, Hilchie D, He H, Fang Y, Moons L, Carmeliet P, Foster RA, Croy BA. 2007. Genetic deletion of placenta growth factor in mice alters uterine NK cells. J Immunol 178: $4267-4275$.

Taylor AP, Goldenberg DM. 2007. Role of placenta growth factor in malignancy and evidence that an antagonistic PlGF/Flt-1 peptide inhibits the growth and metastasis of human breast cancer xenografts. Mol Cancer Ther 6: $524-531$.

Taylor AP, Leon E, Goldenberg DM. 2010. Placental growth factor (PlGF) enhances breast cancer cell motility by mobilising ERK1/2 phosphorylation and cytoskeletal rearrangement. Br J Cancer 103: 82-89.

Torry RJ, Tomanek RJ, Zheng W, Miller SJ, Labarrere CA, Torry DS. 2009. Hypoxia increases placenta growth factor expression in human myocardium and cultured neonatal rat cardiomyocytes. J Heart Lung Transplant 28: 183-190.

Tsao PN, Su YN, Li H, Huang PH, Chien CT, Lai YL, Lee CN, Chen CA, Cheng WF, Wei SC, et al. 2004. Overexpression of placenta growth factor contributes to the pathogenesis of pulmonary emphysema. Am J Respir Crit Care Med 169: 505-511.

Van de Veire S, Stalmans I, Heindryckx F, Oura H, TijerasRaballand A, Schmidt T, Loges S, Albrecht I, Jonckx B, Vinckier S, et al. 2010. Further pharmacological and genetic evidence for the efficacy of PlGF inhibition in cancer and eye disease. Cell 141: 178-190.

Vanheule E, Fan YD, Van Huysse J, Meester D, Olievier K, Praet M, de Hemptinne B, Colle I. 2010. Expression of placental growth factor in regenerating livers after partial hepatectomy in the rat. Eur J Gastroenterol Hepatol 23: 66-75.

Van Steenkiste C, Geerts A, Vanheule E, Van Vlierberghe H, De Vos F, Olievier K, Casteleyn C, Laukens D, De Vos M, Stassen JM, et al. 2009. Role of placental growth factor in mesenteric neoangiogenesis in a mouse model of portal hypertension. Gastroenterology 137: 2112-2124. 
M. Dewerchin and P. Carmeliet

Van Steenkiste C, Ribera J, Geerts A, Pauta M, Tugues S, Casteleyn C, Libbrecht L, Olievier K, Schroyen B, Reynaert H, et al. 2011. Inhibition of placental growth factor activity reduces the severity of fibrosis, inflammation, and portal hypertension in cirrhotic mice. Hepatology 53: 16291640.

Verhaeghe C, Tabruyn SP, Oury C, Bours V, Griffioen AW. 2007. Intrinsic pro-angiogenic status of cystic fibrosis airway epithelial cells. Biochem Biophys Res Commun 356: $745-749$.

Viglietto G, Romano A, Manzo G, Chiappetta G, Paoletti I, Califano D, Galati MG, Mauriello V, Bruni P, Lago CT, et al. 1997. Upregulation of the angiogenic factors PlGF, VEGF and their receptors (Flt-1, Flk-1/KDR) by TSH in cultured thyrocytes and in the thyroid gland of thiouracil-fed rats suggest a TSH-dependent paracrine mechanism for goiter hypervascularization. Oncogene 15: 2687-2698.

Wei SC, Tsao PN, Yu SC, Shun CT, Tsai-Wu JJ, Wu CH, Su YN, Hsieh FJ, Wong JM. 2005. Placenta growth factor expression is correlated with survival of patients with colorectal cancer. Gut 54: 666-672.

Wirzenius M, Tammela T, Uutela M, He Y, Odorisio T, Zambruno G, Nagy JA, Dvorak HF, Yla-Herttuala S, Shibuya $M$, et al. 2007. Distinct vascular endothelial growth factor signals for lymphatic vessel enlargement and sprouting. J Exp Med 204: 1431-1440.

Wu XZ, Xie GR, Chen D. 2007. Hypoxia and hepatocellular carcinoma: The therapeutic target for hepatocellular carcinoma. J Gastroenterol Hepatol 22: 1178-1182.

Xu L, Jain RK. 2007. Down-regulation of placenta growth factor by promoter hypermethylation in human lung and colon carcinoma. Mol Cancer Res 5: 873-880.

Xu L, Cochran DM, Tong RT, Winkler F, Kashiwagi S, Jain RK, Fukumura D. 2006. Placenta growth factor overexpression inhibits tumor growth, angiogenesis, and metastasis by depleting vascular endothelial growth factor homodimers in orthotopic mouse models. Cancer Res 66: 3971-3977.

Xu Y, Hu HQ, Luo SP, Sun YN, Zhou Q, Chen Z, Song SQ, Zhou Q. 2010. P16, a novel monoclonal antibody specifically recognizing human placental growth factor (PlGF), blocks PIGF-VEGFR1 interaction in vitro and inhibits angiogenesis and tuor growth in vivo. In Proceedings of the 101st Annual Meeting of the American Association for Cancer Research, 2010 Apr 17-21. AACR, Washington, DC.
Yang W, Ahn H, Hinrichs M, Torry RJ, Torry DS. 2003. Evidence of a novel isoform of placenta growth factor (PlGF-4) expressed in human trophoblast and endothelial cells. J Reprod Immunol 60: 53-60.

Yano K, Liaw PC, Mullington JM, Shih SC, Okada H, Bodyak N, Kang PM, Toltl L, Belikoff B, Buras J, et al. 2006. Vascular endothelial growth factor is an important determinant of sepsis morbidity and mortality. J Exp Med 203: $1447-1458$.

Yano K, Okada Y, Beldi G, Shih SC, Bodyak N, Okada H, Kang PM, Luscinskas W, Robson SC, Carmeliet P, et al. 2008. Elevated levels of placental growth factor represent an adaptive host response in sepsis. J Exp Med 205: 2623-2631.

Yao YG, Yang HS, Cao Z, Danielsson J, Duh EJ. 2005. Upregulation of placental growth factor by vascular endothelial growth factor via a post-transcriptional mechanism. FEBS Lett 579: 1227-1234.

Yao J, Wu X, Zhuang G, Kasman IM, Vogt T, Phan V, Shibuya M, Ferrara N, Bais C. 2011. Expression of a functional VEGFR-1 in tumor cells is a major determinant of anti-PlGF antibodies efficacy. Proc Natl Acad Sci 108: 11590-11595.

Yonekura H, Sakurai S, Liu X, Migita H, Wang H, Yamagishi S, Nomura M, Abedin MJ, Unoki H, Yamamoto Y, et al. 1999. Placenta growth factor and vascular endothelial growth factor $\mathrm{B}$ and $\mathrm{C}$ expression in microvascular endothelial cells and pericytes. Implication in autocrine and paracrine regulation of angiogenesis. J Biol Chem 274: 35172-35178.

Yoo SA, Yoon HJ, Kim HS, Chae CB, De Falco S, Cho CS, Kim WU. 2009. Role of placenta growth factor and its receptor flt-1 in rheumatoid inflammation: A link between angiogenesis and inflammation. Arthritis Rheum 60: 345-354.

Ziche M, Maglione D, Ribatti D, Morbidelli L, Lago CT, Battisti M, Paoletti I, Barra A, Tucci M, Parise G, et al. 1997. Placenta growth factor- 1 is chemotactic, mitogenic, and angiogenic. Lab Invest 76: 517-531.

Zohlnhofer D, Brand K, Schipek K, Pogatsa-Murray G, Schomig A, Neumann FJ. 2000. Adhesion of monocyte very late antigen- 4 to endothelial vascular cell adhesion molecule-1 induces interleukin-1 $\beta$-dependent expression of interleukin-6 in endothelial cells. Arterioscler Thromb Vasc Biol 20: 353-359. 


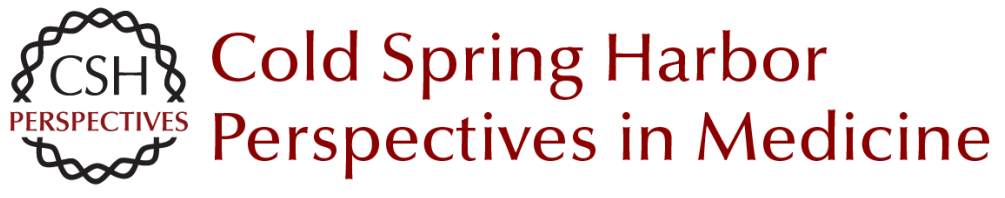

\section{PIGF: A Multitasking Cytokine with Disease-Restricted Activity}

Mieke Dewerchin and Peter Carmeliet

Cold Spring Harb Perspect Med 2012; doi: 10.1101/cshperspect.a011056 originally published online April 4, 2012

\section{Subject Collection Angiogenesis}

Extracellular Matrix Regulation of Vascular Morphogenesis, Maturation, and Stabilization George E. Davis and Scott S. Kemp

Endothelial Cell-Pericyte Interactions in the Pathogenesis of Cerebral Cavernous Malformations (CCMs) Wang Min and Jenny Huanjiao Zhou

Lymphatic Clearance and Pump Function Jerome W. Breslin

Platelets and (Lymph)angiogenesis Harvey G. Roweth and Elisabeth M. Battinelli

Modeling Brain Vasculature Immune Interactions In Vitro Ruth Lyck, Hideaki Nishihara, Sidar Aydin, et al.

Human Endothelial Colony-Forming Cells Juan M. Melero-Martin

\section{The Beauty and Complexity of Blood Vessel} Patterning

Victoria L. Bautch and Yoh-suke Mukouyama

Endothelialitis, Microischemia, and

Intussusceptive Angiogenesis in COVID-19 Steven J. Mentzer, Maximilian Ackermann and Danny Jonigk
Regulation of the Blood-Brain Barrier in Health and Disease Cara C. Rada, Kanako Yuki, Jie Ding, et al.

Targeting Angiogenesis via Resolution of Inflammation

Abigail G. Kelly and Dipak Panigrahy

Notch Signaling in the Vasculature: Angiogenesis and Angiocrine Functions

Sana S. Hasan and Andreas Fischer

Signal Transduction and Gene Regulation in the Endothelium

Michel V. Levesque and Timothy Hla

Buttons and Zippers: Endothelial Junctions in

Lymphatic Vessels

Peter Baluk and Donald M. McDonald

Endothelial Cell Fate Determination: A Top Notch Job in Vascular Decision-Making

L.A. Naiche, Stephanie R. Villa and Jan K. Kitajewski

Leukocyte Trafficking in Lymphatic Vessels Aline Bauer, Hazal Tatliadim and Cornelia Halin

Lymphatic Tissue and Organ Engineering for In Vitro Modeling and In Vivo Regeneration Anna M. Kolarzyk, Gigi Wong and Esak Lee

For additional articles in this collection, see http://perspectivesinmedicine.cshlp.org/cgi/collection/ 